\title{
Circadian rhythms in the locomotor activity of the spiders Carrhotus xanthogramma (Salticidae) and Philodromus cespitum (Philodromidae): Temporal patterns and sexual differences
}

\author{
LÁsZló MEZŐFI ${ }^{1}$, GÁbor MARKÓ ${ }^{2,3}$, PÉTER KOVÁCS ${ }^{4}$ and VIKTOR MARKÓ ${ }^{1}$ \\ ${ }^{1}$ Department of Entomology, Szent István University, Ménesi út 44, Budapest 1118, Hungary; e-mails: mezofilaszlo@gmail.com, \\ marko.viktor@kertk.szie.hu \\ 2 Department of Plant Pathology, Szent István University, Ménesi út 44, Budapest 1118, Hungary; \\ e-mail: marko.gabor3@gmail.com \\ ${ }^{3}$ Behavioural Ecology Group, Department of Systematic Zoology and Ecology, Eötvös Loránd University, Pázmány P. sétány \\ $1 / \mathrm{C}$, Budapest 1117, Hungary \\ ${ }^{4}$ Mining and Geological Survey of Hungary, Columbus utca 17-23, Budapest 1145, Hungary; e-mail: kovacs.retep@gmail.com
}

Key words. Araneae, Carrhotus xanthogramma, Philodromus cespitum, diel activity, circadian rhythm, activity profile, ultradian rhythmicity, locomotor activity, sexual differences, natural photoperiod, temporal niche, beneficial arthropods

\begin{abstract}
Circadian rhythms play an essential role in the adaptation of organisms to the environment and may show species-specific or sex-specific differences even within a closely related taxonomic group. Although spiders (Araneae) are sexually dimorphic in several morphological and behavioural features, there are very few studies on the sex-specific differences in their biological rhythms. This study evaluated the circadian rhythm in the locomotor activity of two agrobiont hunting species of spider, Carrhotus xanthogramma (Latreille, 1819) (Salticidae) and Philodromus cespitum (Walckenaer, 1802) (Philodromidae), under natural photoperiod conditions. Particular attention was paid to possible differences between the sexes in both species. We found that C. xanthogramma is a strictly diurnal species with a mean activity peak in the morning in both sexes and the females are more active than males. The locomotor activity rhythm of males was richer in ultradian (shorter than a day but longer than an hour) components, although the relative power of these components was negligible compared to the main, 24-h period component. In accordance with these results, the diel pattern of locomotor activity of $C$. xanthogramma can be described by a unimodal cosine curve. In contrast to C. xanthogramma, both sexes of Ph. cespitum showed cathemeral activity (i.e., activity occur within both the light and dark portions of the daily cycle) and females and males follow quite different activity schedules: females were most active at night, shortly before nautical dawn, whereas males were most active early in the morning. Unlike $C$. xanthogramma, $P h$. cespitum has more ultradian components, with higher relative power especially in females, where besides the 24-h circadian component there is a particularly strong 12-h ultradian period. Based on these factors, females of Ph. cespitum show a bimodal and males a unimodal pattern.
\end{abstract}

\section{INTRODUCTION}

There are temporal periodicities in several physiological processes and behaviours of animals that are called circadian rhythms if the period is approximately $24 \mathrm{~h}$. These rhythms are often regulated by both endogenous and exogenous cues. One of the most important exogenous cues is the natural light-dark cycle. A well synchronized circadian rhythm is an essential feature of the adaptation of organisms to their environment, as the entrained rhythm may allow the organism to act proactively to a periodic environmental stimulus (Refinetti, 2016). Furthermore, adaptation to different temporal niches (e.g., diurnal or nocturnal) affect resource availability, the risk of predation and rate of encounter with competitors (Kronfeld-Schor \& Dayan, 2003). For example, the Batesian myrmecomorphic spider
Micaria sociabilis Kulczyński, 1897 (Gnaphosidae), like the species it mimics, is diurnal, whereas its close relatives are nocturnal. Although this spider does not feed on ants, co-occurrence with its models seems to provide it with a defensive advantage (e.g., protection from model-averse predators) (Pekár \& Jarab, 2011). In addition, the nature of a spider's diel activity pattern may influence the composition of its prey and, through this, the pest suppression ability of agrobiont spiders (Herberstein \& Elgar, 1994; Marc et al., 1999; Tietjen \& Cady, 2007).

Many studies report diel activity and biological rhythms in spiders (e.g., Cloudsley-Thompson, 1981; Ortega et al., 1992; Kovoor et al., 1995, 1999; Yamashita \& Nakamura, 1999; Ortega-Escobar, 2002a; Nørgaard et al., 2006; Jones et al., 2011, 2018; Moore et al., 2016). The diel rhythm in 
locomotor activity in spiders can be circadian (CloudsleyThompson, 1987, 2000), higher-frequency (ultradian) endogenous rhythms can control their motor activity (Suter, 1993), they may not be purely nocturnal or diurnal (Suter \& Benson, 2014) and even the locomotor activity of cavedwelling species may be controlled by free-running circadian rhythms (Soriano-Morales et al., 2013). However, less attention has been given to sexual differences among spiders in either their rhythmic processes or diel activity (e.g., Schmitt et al., 1990; Krumpalová \& Tuf, 2013).

Sex-specific selection pressures can result in sexual dimorphism in the physiology, morphology, or behaviour of animals (Slatkin, 1984). In the case of spiders, males are usually more active/mobile than females, partly because besides foraging they also must find females for mating (Sullivan \& Morse, 2004; Framenau, 2005; Foelix, 2011). Pitfall traps tend to catch more males than females of spiders (e.g., lycosids, thomisids and salticids) (Topping \& Sunderland, 1992; Prószynski \& Lubin, 1993; Fujii, 1997; Bogya \& Markó, 1999), while on trees, males of the nocturnal spiders Cupiennius spp. (Ctenidae) are more active than females (Schmitt et al., 1990). Furthermore, there might be differences between the sexes in when they are active (Krumpalová \& Tuf, 2013), or other features such as body size (Head, 1995), certain morphological traits (Albín et al., 2018), metabolic rate (Kotiaho, 1998), or even immune response (Rádai et al., 2018), due to sex-specific selection pressures that may result in sex-specific differences in such features (Turk et al., 2018).

For this study, we chose two canopy dwelling hunting species of spiders, Carrhotus xanthogramma (Salticidae) and Philodromus cespitum (Philodromidae), which are very abundant and thus may play a role as natural enemies of certain invertebrate pests in Hungarian pome fruit orchards (Mezőfi et al., 2018).

Like other salticids (Jackson \& Pollard, 1996), the jumping spider C. xanthogramma is a diurnal hunter with excellent eyesight that belongs to the guild of stalkers (Uetz et al., 1999). C. xanthogramma is distributed from Europe to Japan (WSC, 2018), and is one of the most common species of spider in the canopy of pome fruit orchards in Hungary (Bogya et al., 1999a, b, 2000; Markó \& Keresztes, 2014). Mature individuals occur mostly in April and May. C. xanthogramma can dominate the arboreal spider assemblage in apple orchards, and presumably, it is a significant intraguild predator of other spiders (Markó \& Keresztes, 2014). While a handful of earlier studies have dealt specifically with this species (e.g., Yoshida \& Suzuki, 1981; Maekawa \& Ikeda, 1992; Fang et al., 2016), none have examined its diel rhythm.

Philodromus cespitum is considered a diurnal hunter (Pekár, 1999a; Korenko et al., 2010), and, as with other philodromids, it belongs to the guild of ambush hunters (Uetz et al., 1999). Ph. cespitum is widely distributed in the Holarctic region (WSC, 2018) and while it can be the dominant species in canopy-dwelling spider assemblages in apple orchards in Europe (Bogya et al., 1999b; Pekár, 1999b; Pekár \& Kocourek, 2004), it can also be abundant in North American orchards (Miliczky et al., 2008; Sackett et al., 2008). Adult Ph. cespitum are most common in June and July (Miliczky et al., 2008), and this species is a potential biological control agent (Wisniewska \& Prokopy, 1997; Ghavami, 2008; Michalko \& Pekár, 2015; Pekár et al., 2015; Lefebvre et al., 2017; Michalko et al., 2017), although pesticide applications could reduce its ability to

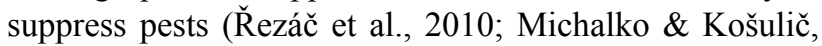
2016).

The aim of this study was to describe the diel pattern of locomotor activity and certain features of the rhythms, with special attention to sexual differences, in C. xanthogramma and $P h$. cespitum, two hunting species of spider very abundant in fruit orchards in Hungary. We hypothesized that (1) both species are diurnal, i.e., activity is not uniformly distributed throughout the day, (2) their rhythms are circadian, and (3) the patterns contain ultradian components. Furthermore, we hypothesized that there is sexual dimorphism in certain features of the species' rhythms, i.e., (4) that males have higher locomotor activity compared to conspecific females, and, in connection with this, (5) locomotor activity rhythms of males contain more high-frequency components than those of females.

\section{MATERIAL AND METHODS}

\section{Test animals}

Spiders used in the experiments were collected by beating the canopies of apple trees in various orchards in Hungary. The collected individuals were transported to the Department of Entomology at Szent István University, where the study was carried out. We collected 10 adult males and 11 adult females of C. xanthogramma (later one female had to be excluded from the analysis) in Újfehértó, on 16 April 2016. We also collected 312 Philodromus spp. individuals (mostly juveniles) for another study from various orchards between 9 and 26 May 2016. Ph. cespitum belongs to the $P h$. aureolus species group, in which the species can be distinguished from one another only by the details of the copulatory organs (Kubcová, 2004), and thus juvenile specimens cannot be determined to species. The spiders were, therefore, raised to the adult stage (on Drosophila hydei Sturtevant, 1921) in the laboratory, and, when the vast majority of spiders had matured, we randomly selected 11 females and 11 males of $P h$. cespitum (later two males had to be excluded from the analysis). Data on collected specimens and information on collecting sites are listed in Supplement S1.

The collected spiders (both C. xanthogramma and Ph. cespitum) were housed individually in plastic Petri dishes (height: 16 $\mathrm{mm}$, outer diameter: $61 \mathrm{~mm}$ ) and placed in random order on plastic trays. The sides of the Petri dishes were covered with white tape to reduce disturbance from neighbouring spiders. At the end of the study the body mass of C. xanthogramma and Ph. cespitum (see Supplement S1) were measured using an analytic scale (OHAUSE Adventurer Pro AV 114 C) and the previous identification of the specimens confirmed using the keys of Kubcová (2004) and Nentwig et al. (2018).

\section{Animal housing}

All spiders were kept and our tests carried out in a behavioural laboratory at the Department of Entomology (Budapest, Hungary, $47^{\circ} 28^{\prime} 50^{\prime \prime} \mathrm{N}, 19^{\circ} 02^{\prime} 25^{\prime \prime} \mathrm{E}, 125 \mathrm{~m}$ a.s.1.). The plastic trays holding the Petri dishes with spiders were surrounded with a cardboard panel, and to minimize human disturbance, we only went into 
the room to check the experiment. Because the examination of circadian behaviour under more natural conditions allows a more accurate interpretation of certain rhythmic processes (Vanin et al., 2012; Menegazzi et al., 2013), the spiders' circadian activity was examined under natural light and photoperiod. The spiders were not exposed to direct sunlight, and the temperature and relative humidity in the room were approximately similar to outside conditions.

\section{Recording locomotor activity}

To monitor the spiders' locomotor activity, the activity of all individuals were simultaneously recorded with a video camera (Panasonic HC-X920 HD) for $72 \mathrm{~h}$ (as per Schmitt et al., 1990). During the scotophase, a red LED corn bulb (unbranded, $2.5 \mathrm{~W}$, $200 \mathrm{Lm}$, emission peak at $632 \mathrm{~nm}$ wavelength) illuminated the recording area between 19:00 p.m. (before twilight) and 8:00 a.m. Because red light is on the verge of perception by spiders (Yamashita, 2002), exposure to red light did not influence their activity (Ortega-Escobar, 2002b). Activity was recorded from 26 to 29 April in the case of $C$. xanthogramma and 6-9 July in the case of Ph. cespitum. During these periods, the room temperature and the relative humidity were also recorded. Environmental conditions for the experiments are shown in Table 1. The exact time of sunrise, sunset, nautical and civil twilights (sun between $12^{\circ}$ $6^{\circ}$ and $6^{\circ}-0^{\circ}$ below the horizon) were calculated using the database available at the United States Naval Observatory (USNO, 2018), and the times were expressed as Central European Summer Time (CEST) (Table 1). To calculate the approximate photoperiods, civil twilight was used as a reference for the beginning and end of the day, because the start of civil twilight at dawn and the end of civil twilight at dusk are often considered the times of "lights on" and "lights off" for biological systems (Hut et al., 2013). Spiders were placed in the final layout three days before the tests and from this time to the end of the study food and water were not provided.

Video recordings were analysed with a $10-$ min resolution. For this, the recordings were manually stopped at 10-min intervals using Solomon Coder software (Péter, 2011) and the same observer examined whether there was a movement within the given 10 -min period. The level of activity was scored on a scale of $0-2$ in each interval ( 0 - zero locomotion; 1 - minimal change in body position or the locomotion was shorter than the body length of the individual; and 2 - the locomotion was longer than the length of the individual). Applying this scoring procedure, we obtained a time series of 432 activity records (72-h long time series) for each individual.

\section{Data analysis}

\section{(1) Quantifying the relative amount of activity}

To quantify the relative amount of activity during the photophase and during twilight periods, we calculated diurnality and crepuscularity indices according to Ensing et al. (2014). For the diurnality index, the light phase of the day was defined as the time between the start of civil dawn and the end of civil dusk, and the remainder of the day was considered "night". For the crepuscularity index, "twilight" was defined as the time from the start of nautical dawn until sunrise and from sunset until the end of nautical dusk (Ensing et al., 2014). The following equations were used to calculate the indices:

$$
I_{\text {diurnality }}=\frac{a c t_{\text {day }}-a c t_{\text {night }}}{a c t_{\text {day }}+a c t_{\text {night }}}
$$

and

$$
I_{\text {crepuscularity }}=\frac{a c t_{\text {twilight }}-a c t_{\text {non-twilight }}}{a c t_{\text {twilight }}+a c t_{\text {non-twilight }}}
$$

where $a c t_{d a y}$ is the average activity level in the light phase of the day, act ${ }_{\text {night }}$ is the average activity level at night, act twilight $_{\text {is }}$ the average activity level during twilight, and act ${ }_{n o n-\text { twilight }}$ is the average activity level during the remainder of the day (Ensing et al., 2014). Student's t-test was used to compare the means of the index values between sexes, and $\mathrm{R}$ software version 3.5.1 ( $\mathrm{R}$ Core Team, 2018) was used for further analyses (but see Fourier analyses below).

\section{(2) Circular statistical analysis of the activity pattern}

Circular statistics were used to examine the temporal distribution of locomotor activity in different spider groups (females or males within a species) and to compare the diel activities of the sexes. For circular statistics, the activity dataset was transformed as follows: first, for each group, the average activity levels were computed at 10-min intervals; second, the computed activity values were rounded to one decimal place and multiplied by ten to get an integer. These integers were then treated as the activity level in a given 10-min interval for a particular group. Thereafter, as in Fontúrbel et al. (2014), Rao's spacing test of uniformity was conducted to determine if the records were non-randomly distributed over the day. After this, the circular mean (the direction of the resultant vector or mean activity peak), the mean resultant length ( $R$, a measure of data concentration or angular dispersion) and the bootstrap confidence intervals $(95 \% \mathrm{CI})$ of mean direction were estimated. $R$ values range from 0 to 1 , where values close to 1 indicate an activity peak at a given moment and values close to 0 indicate a cathemeral activity pattern (i.e., activity at any time during the daily cycle) (Tattersall, 1987; Ranganathan et al., 2010). To compare activity patterns of the sexes, a nonparametric Watson's two-sample test of homogeneity (or Watson's $\mathrm{U}^{2}$ test) was used. The square-roots of the activity levels throughout the day were plotted (at 30-min intervals) on a circular histogram (rose diagram). For the circular statistics, the "circular" package in $\mathrm{R}$ environment was used.

\section{(3) Comparing activity in different temporal windows}

The observation days were divided into six temporal periods: nautical dawn $\left(\right.$ dawn $\left._{\mathrm{n}}\right)$, civil dawn $\left(\right.$ dawn $\left._{\mathrm{c}}\right)$, the period between sunrise and sunset (daytime), civil dusk (dusk ${ }_{c}$ ), nautical dusk (dusk $\mathrm{n}_{\mathrm{n}}$ ) and the period between the end of nautical dusk and the

\begin{tabular}{|c|c|c|c|c|c|c|c|c|c|c|}
\hline Species & $\begin{array}{c}\text { Activity } \\
\text { monitoring }\end{array}$ & $\begin{array}{c}\text { Approx. } \\
\text { Civil LD (h) }\end{array}$ & $\begin{array}{l}\text { Nautical } \\
\text { Dawn }\end{array}$ & $\begin{array}{c}\text { Civil } \\
\text { Dawn }\end{array}$ & Sunrise ${ }^{b}$ & Sunset ${ }^{b}$ & $\begin{array}{c}\text { Civil } \\
\text { Dusk }^{b}\end{array}$ & $\begin{array}{l}\text { Nautical } \\
\text { Dusk }^{b}\end{array}$ & $\begin{array}{c}\text { Avg. T } \\
\left({ }^{\circ} \mathrm{C} \pm \mathrm{SE}\right)^{\mathrm{c}}\end{array}$ & $\begin{array}{c}\text { Avg. Rel. Hum. } \\
(\% \pm \mathrm{SE})^{c}\end{array}$ \\
\hline C. xanthogramma & $\begin{array}{l}2016.04 .26 .8: 00 \\
2016.04 .29 .8: 00\end{array}$ & $15.5 / 8.5$ & $4: 16-4: 58$ & $4: 58-5: 32$ & $5: 32$ & $19: 50$ & $19: 50-20: 24$ & $20: 24-21: 07$ & $18.5(0.06)$ & $39.6(0.16)$ \\
\hline Ph. cespitum & $\begin{array}{l}2016.07 .06 .8: 00 \\
2016.07 .09 .8: 00\end{array}$ & $17 / 7$ & $3: 23-4: 16$ & $4: 16-4: 56$ & $4: 56$ & $20: 42$ & $20: 42-21: 22$ & $21: 22-22: 15$ & $28.1(0.03)$ & $25.7(0.20)$ \\
\hline
\end{tabular}

Table 1. Environmental conditions recorded during the experiment.

a approximate Light/Dark (LD) cycle where photophase was defined as time between the start of civil dawn and the end of civil dusk; ${ }^{\mathrm{b}}$ obtained from the online database of the United States Naval Observatory (USNO, 2018), three days average expressed as CEST; ${ }^{\circ}$ measured during the experiment. 
beginning of nautical dawn (night-time) (see details in Table 1). As the length of these temporal windows differed, the mean activity level (mean activity score per hour) was calculated for each individual and period in order to make the data comparable.

The relationships between activity levels and the temporal windows was analysed using a Linear Mixed-Effect Model (LMM) with the following statistical model structure applied to the "Ime4" package in the R environment. We entered the standardized activity level as a response variable with temporal window as focal predictor. The variable containing the identification numbers of the focals were entered as a random factor. We ran the same statistical model structure for females and males of both species, but separately. For testing the post-hoc differences in the mean activity level between the different temporal windows within sexes, we applied Student's t-test with the adjustment of the $P$-values using "Holm" correction due to the planned multiple comparisons.

(4) Analysis of the periodicities in activity patterns using discrete Fourier transformation

To examine the periodicities in the activity patterns (see Supplement S2), a discrete Fourier transform (DFT) analysis was applied, using self-made Matlab (The MathWorks Inc., 2015) routines. For this, the noisiness of the original 72-h-long time series was suppressed by compiling the moving averages with six-element $(1 \mathrm{~h})$ sliding-windows. This results in the spectral elements of the signal belonging to frequencies bigger than $1 / \mathrm{h}(24$ cycles/day) were filtered out. On the other hand, the smallest limit of the investigated range of the spectra was set to 1/day, since the daily activity rhythm is already clearly exemplified by the three day long records of the spider's movements. For both species, the biggest part of the power of the activity signals is contained by spectral components belonging to cycles below 20/day. It doesn't necessarily demonstrate the absence of more frequent (frequencies bigger than 24/day) spider activities, but we suspect that the measurement procedure is simply not able to resolve finer details in the ultradian rhythms of the individuals. The statistical significance of the spectral peaks has been evaluated according to the method introduced by Forrest \& Suter (1994). Briefly, this method identifies a spectral peak as significant if the appearance of its power in the spectrum of a random process is less probable than a certain $\alpha$ threshold. In our analysis, we apply $\alpha=0.01$ probability threshold that corresponds to a power limit $L$ of $9.210 / N$ ( $N$ being the number of signal elements), that is, any spectral peak exceeding $L$ were considered significant. In the following steps, we used the relative powers of the spectral components, computed as the ratio between the computed powers and the power limit, $P / L$. This choice enables the quantitative comparison of the statistical significance of spectral elements deriving from the analyses of different length time-series.

To investigate species-level behaviours, we constructed two types of bar graphs attributing the relevance of daily and ultradian periodicities for each species based on the spectral parameters of the individuals (see Supplement S3). The first bar plot (Fig. 4 left side) concerns the probability that a given cycle appears in the ultradian periodicities of a species. The bar heights in the plot represent the ratios of the number of spiders exhibiting periodical behaviour in a given cycle and the total number of spiders of a given sex analysed. The second bar graph (Fig. 4 right side) shows the mean values of the relative powers of the statistically significant peaks observed for any individuals of a given species or sex in terms of the number of ultradian cycles. The means are normalized relative to the largest mean value, i.e. the highest bar corresponds to a value of unity.

\section{(5) Cosinor-based analysing of the activity rhythm}

Fourier analysis indicated that a 24 -h activity rhythm is prominent for the locomotor behaviour of both species; therefore we used cosinor-based rhythmometry to quantify and compare the circadian rhythms of activity in males and females (Cornelissen, 2014). First, we described the individual-based differences in the activity level by fitting Nonlinear Mixed-Effects Models (R package: "nlme") characterized by a cosine function. We applied the following formula with a fixed 24-h period:

$\mathrm{y}=\mathrm{p} 1+\mathrm{p} 2 \times \cos [2 \pi / 24(\mathrm{x}-\mathrm{p} 4)]$,

where $\mathrm{y}$ was the estimated activity level, $\mathrm{x}$ was the time in hours, p1 was the midline estimating statistic of rhythm (mesor), p2 was the distance above the mesor (amplitude) and p4 was the phase delay of the first peak.

The response variable of the statistical model was the diel activity rhythm (24 h-long, average of the three-day-long time series). The statistical model also included a variable containing the identification numbers of the observed individuals as a random factor. We ran these statistical models separately for each species. After the successful fitting of the cosine function, we also tested the significance of the model parameters of the nonlinear statistical model.

Second, based on the final model, we extracted the model parameters of the fitted model for characterizing the circadian rhythm of each individual. We calculated the following features: the activity level at the acrophase (time of maximum in the fitted curve, "Max"), the activity level at the bathyphase (time of minimum in the fitted curve, "Min") and the average activity level (midline estimating statistic of rhythm - mesor, "Mean"). After this, we tested the potential differences of the function parameters between sexes within each species. We used LMM in which the calculated activity level was the response variable, while the sex, the type of the function parameter ("Max", "Mean" and "Min") and their interactions were entered as predictor variables in the model. The variable containing the ID numbers was present in the model as a random factor. We applied the Student's t-test for testing the post-hoc differences in the function parameters within and between sexes adjusting the $P$-values by "Holm" correction due to the planned multiple comparisons.

Finally, as a strong second frequency component with a 12-h period was found in the activity pattern of $P h$. cespitum females, a bimodal cosine function was applied. The formula of the bimodal cosine function was:

$\mathrm{y}=\mathrm{p} 1+\mathrm{p} 2\{\cos [2 \pi / 24(\mathrm{x}-\mathrm{p} 4)])\}+\mathrm{p} 5\{\cos [4 \pi / 24(\mathrm{x}-\mathrm{p} 4)]\}$,

where all parameters are already defined above in the formula of the unimodal cosine function except $\mathrm{p} 5$, which indicates the same parameter as $\mathrm{p} 2$ in the secondary cosine function.

\section{RESULTS}

\section{Activity indices}

According to the calculated indices, C. xanthogramma was strictly diurnal and not crepuscular. Females and males did not differ significantly from each other in their relative amounts of diurnal or twilight activity (Fig. 1). Ph. cespitum was active during the whole $24 \mathrm{~h}$ period, and thus cannot be considered either strictly diurnal or nocturnal and cannot be characterized as crepuscular, although it was relatively more active during twilight than C. xanthogramma. According to the Student's t-test Ph. cespitum males were 

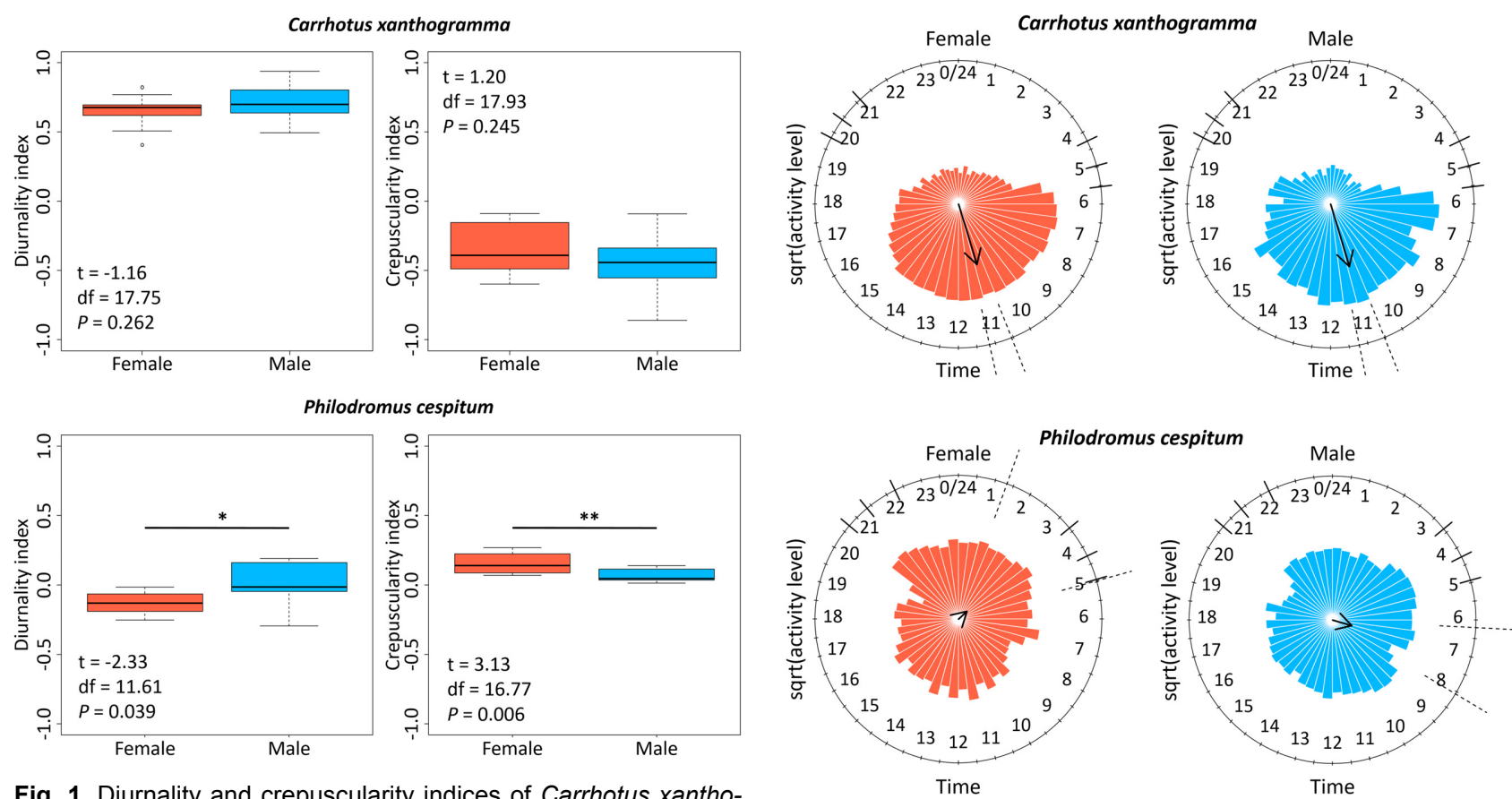

Fig. 1. Diurnality and crepuscularity indices of Carrhotus xanthogramma (above) and Philodromus cespitum (below). The value 0.0 indicates similar activity in each of the periods of a day investigated. The significant differences are indicated by asterisks $\left(^{*}=P\right.$ $<0.05,{ }^{* *}=P<0.01$ ).

more active during daytime than the females, which were significantly more crepuscular than the males (Fig. 1).

Fig. 2. The activity pattern of Carrhotus xanthogramma (above) and Philodromus cespitum (below) females (left) and males (right). The mean activity peak (circular mean) is indicated by the arrow and its length is related to the mean resultant length $(R)$. The square-root of the level of activity was plotted at 30 min intervals. Dashed lines indicate the $95 \%$ confidence intervals of the mean peak activity and the six shorter solid lines indicate the different twilight periods as follow: nautical dawn, civil dawn, sunrise, sunset, civil dusk and nautical dusk (see data in Table 1).
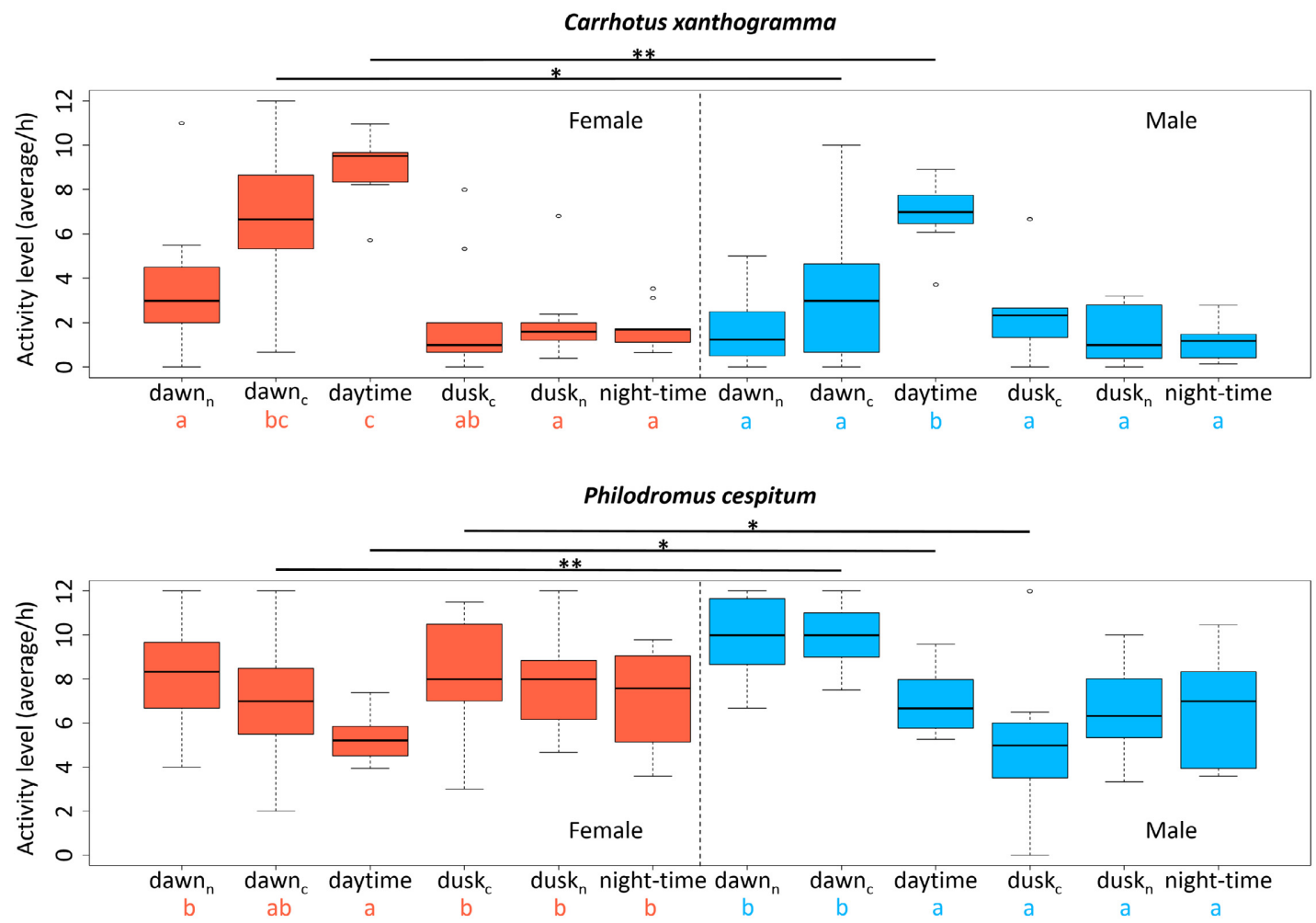

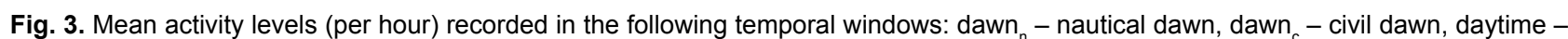
the period between sunrise and sunset, dusk ${ }_{c}$ - civil dusk, dusk ${ }_{n}$ - nautical dusk, night-time - the period between the end of nautical dusk and the beginning of nautical dawn. Within females or males of the given species (above: Carrhotus xanthogramma, below: Philodromus cespitum) the different letters indicate significant differences at $P<0.05$ level. The activity of females and males in the same temporal windows were compared separately and significant differences are indicated by asterisks $\left({ }^{*}=P<0.05,{ }^{* *}=P<0.01\right.$ ). (Note that the lengths of the temporal windows differed, see Table 1). 


\section{Carrhotus xanthogramma}
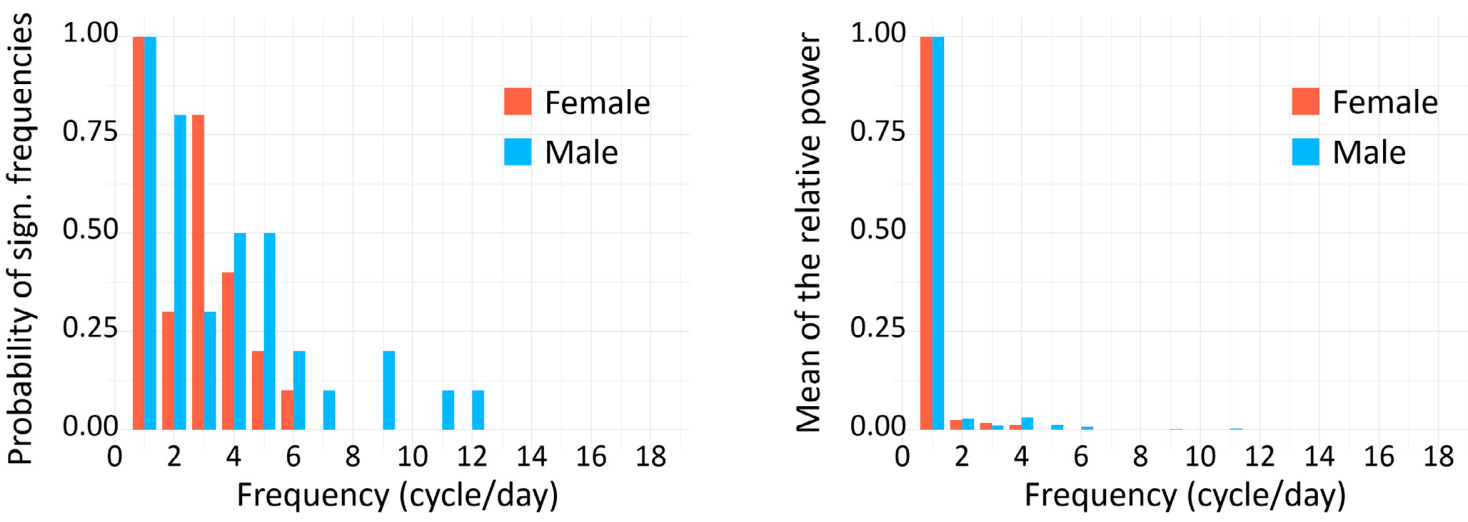

Philodromus cespitum
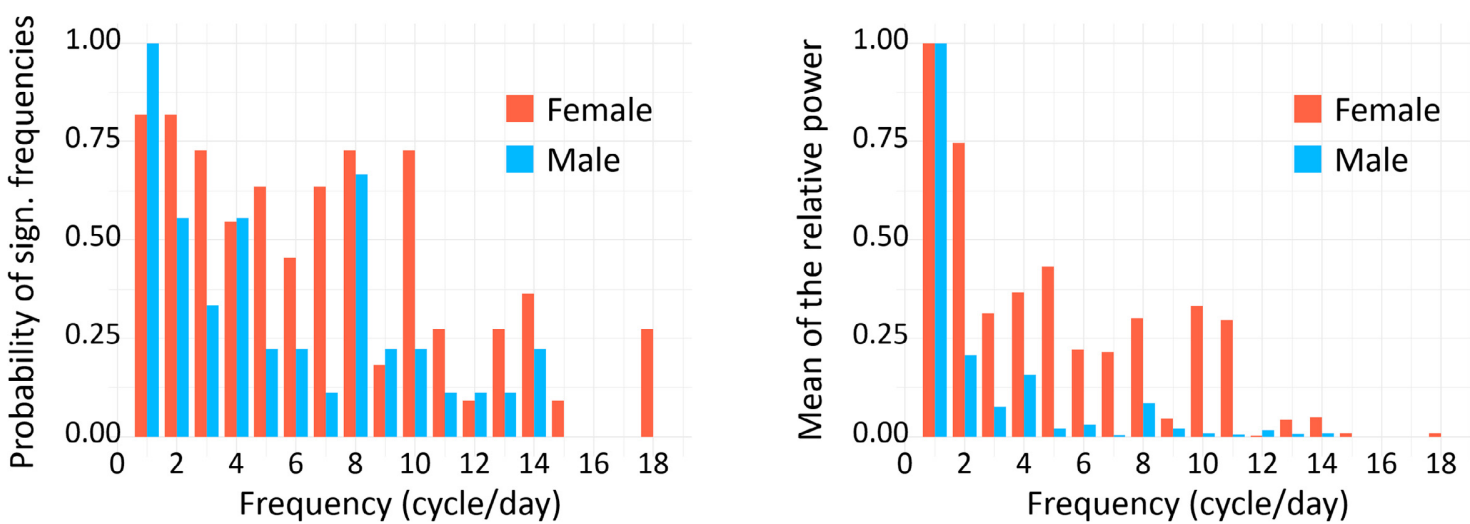

Fig. 4. Results of the Fourier analysis of the time series (72 $\mathrm{h}$ long) recorded for Carrhotus xanthogramma (above) and Philodromus cespitum (below). On the left, we show the probabilities of the appearance of significant peaks in a given number of cycles per day. The probabilities are computed as the ratio between the number of individuals exhibiting a spectral peak (detected at $\alpha<0.01$ level) in a given cycle and the total number of females and males studied. On the right, we show the individual means of the relative powers (i.e. the power of the peak divided by the limit of significance, see text) of the significant spectral peaks for the female and male spiders, in terms of the number of daily cycles. The plotted values are normalized relative to the largest mean value. Significant spectral components were not found beyond 18 cycles/day. (Note that the temporal resolution and high-pass filtering of the activity signals made it possible to clarify the spectral components in the frequency range of 0-24 cycles/day).

\section{Diel distribution of activity}

Circular analysis revealed that the pattern in the locomotor activity of C. xanthogramma (Fig. 2) was not uniformly distributed throughout the day, either in females (Rao's spacing test; $U=325.532, P<0.001$ ) or males (Rao's spacing test; $U=313.879, P<0.001)$. The mean peak of locomotor activity of females occurred at 10:51 (95\% CI $=10: 33$ to $11: 10 ; R=0.437)$ and of males at $10: 53(95 \%$ $\mathrm{CI}=10: 32$ to $11: 14 ; R=0.450)$. Activity patterns of the sexes did not differ (Watson's two-sample test; $U^{2}=0.056$, $P>0.1$ ). As for Ph. cespitum, the activity of the females (Rao's spacing test; $U=324.396, P<0.001$ ) and males (Rao's spacing test; $U=329.506, P<0.001$ ) was also nonrandomly distributed throughout the day. The mean activity peak of the females occurred at 03:09 (95\% CI $=01: 19$ to $04: 58 ; R=0.079)$ while that of males was at 07:07 $(95 \%$ $\mathrm{CI}=06: 12$ to $08: 04 ; R=0.138$ ). The activity patterns (Fig. 2 ) of females and males of $P h$. cespitum differed significantly (Watson's two-sample test; $U^{2}=0.672, P<0.001$ ). For the activity patterns (activity matrices) based on un- transformed time-series of the individual spiders of both species, see Supplement S2.

Analysing the average activity levels at different times in the day, we obtained the following results: the average activity levels of females and males of C. xanthogramma differed significantly throughout the day (females: $F_{5,45}$ $=21.697, P<0.001$; males: $\left.F_{5,45}=22.703, P<0.001\right)$. Females were significantly more active during civil dawn and especially during daytime, while males were significantly more active in daytime than at other times of the day (Fig. 3). Comparing the mean activity level of females and males in the same temporal windows using Student's t-test, revealed that females were significantly more active than males during civil dawn and daytime (dawn $: \mathrm{t}=-2.45$, $\mathrm{df}=18.00, P=0.025$; daytime: $\mathrm{t}=-3.29$, $\mathrm{df}=17.98, P=$ 0.004; Fig. 3).

$P h$. cespitum also differed in the activity levels recorded at different times of the day for both sexes (females: $F_{5,50}$ $=6.411, P<0.001$; males: $\left.F_{5,40}=11.553, P<0.001\right)$. Females were least active during daytime and males most active during nautical- and civil dawn (Fig. 3). Comparison 


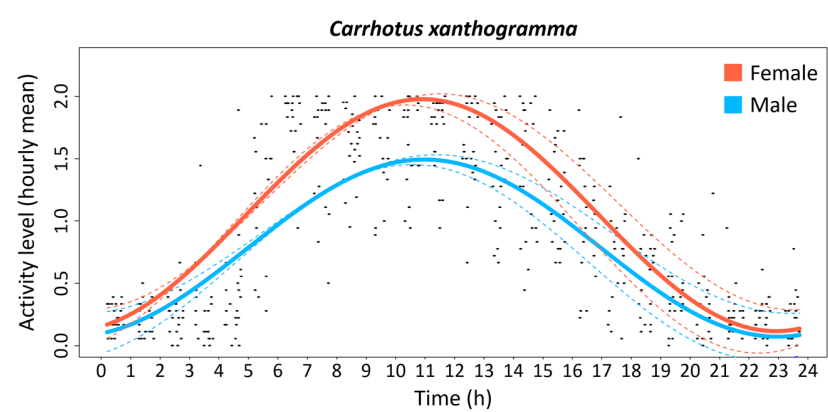

Philodromus cespitum

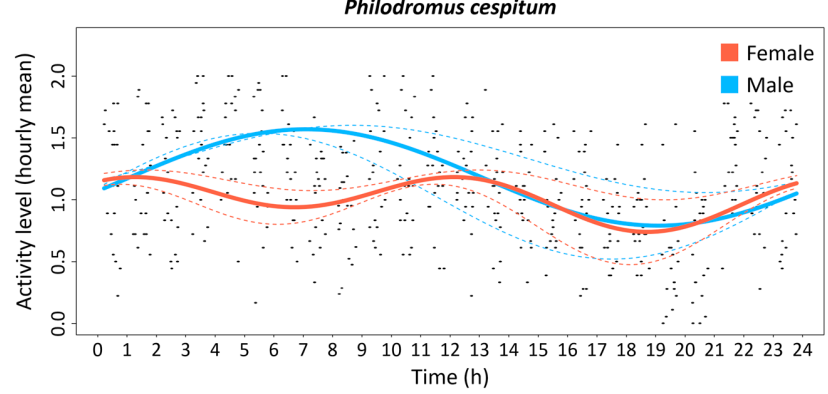

Fig. 5. Daily or $12 \mathrm{~h}$ (see text) locomotor activity rhythms recorded for Carrhotus xanthogramma (above) and Philodromus cespitum (below). Cosine-fitted curve based on the model parameters obtained using a fixed 24-h period). Each dot is the hourly average activity level (jittered) of one individual. Dashed lines indicate the $95 \%$ confidence intervals of the sex-specific fitted curves.

of the activity recorded at particular times of the day using Student's t-test revealed that the males were more active during civil dawn and daytime, and significantly less active during civil dusk than females (dawn $: \mathrm{t}=3.33$, $\mathrm{df}=16.42$, $P=0.004$; daytime: $\mathrm{t}=2.80, \mathrm{df}=14.32, P=0.014$; dusk c $_{\mathrm{c}}$ $\mathrm{t}=-2.60, \mathrm{df}=14.82, P=0.021$; Fig. 3).

\section{Circa- and ultradian rhythmicity}

Fourier analysis revealed that the locomotor activity rhythms of $C$. xanthogramma and Ph. cespitum are circadian, as both species exhibited a single cycle per day as the main frequency component (Fig. 4). Furthermore, for both species, higher-frequency (ultradian), statistically significant components of activity were detected $(\alpha<0.01)$. In $C$. xanthogramma, ultradian rhythmic components were generally more frequent in males than females, although their relative powers were negligible compared to the relative power of the main 24-h period (Fig. 4). Ultradian components present in the activity pattern of at least $50 \%$ of $C$. xanthogramma had a periodicity of $8 \mathrm{~h}$ (3 cycles/day) in females and $12 \mathrm{~h}$ ( 2 cycles/day), $6 \mathrm{~h}$ (4 cycles/day) and 4.8 $\mathrm{h}$ ( 5 cycles/day) in males (Fig. 4$)$.

Philodromus cespitum showed more high-frequency oscillations than C. xanthogramma, and in contrast to C. xanthogramma, the high-frequency components were more common in Ph. cespitum females than males (Fig. 4). The most common (exhibited by at least $50 \%$ of the individuals) ultradian components in the locomotor activity of females and males had periods of $12 \mathrm{~h}$ ( 2 cycles/day), $6 \mathrm{~h}$ (4 cycles/day) and $4 \mathrm{~h}$ (8 cycles/day). The females displayed four additional high-frequency components, with periods of $8 \mathrm{~h}$ ( 3 cycles/day), $4.8 \mathrm{~h}$ ( 5 cycles/day), $3.4 \mathrm{~h}$ ( 7 cycles/
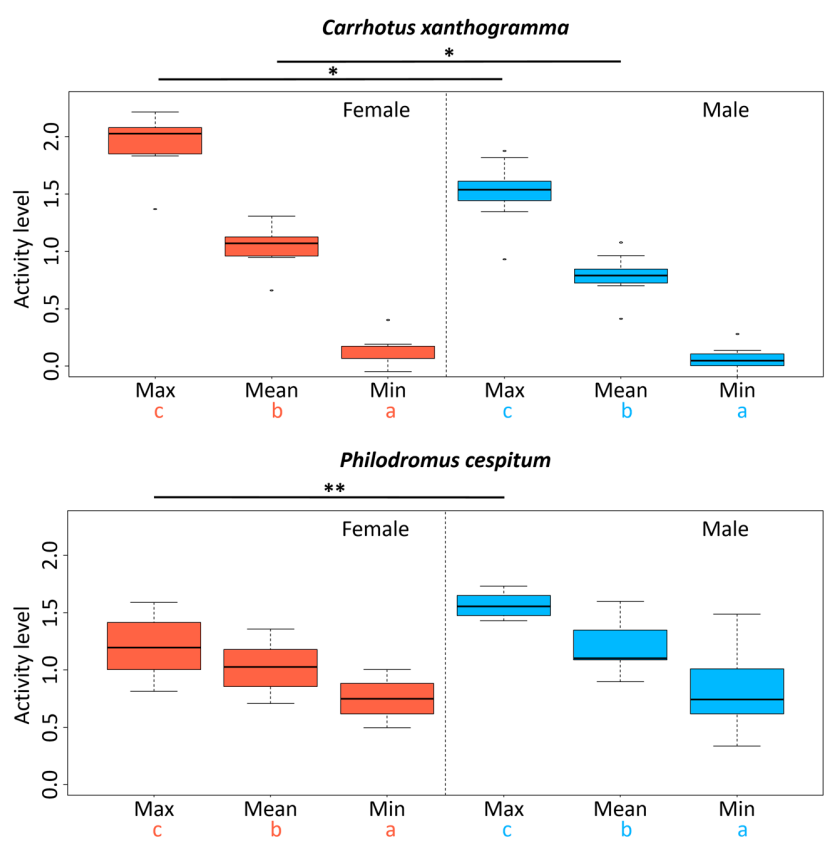

Fig. 6. Sex-related differences in the activity levels at different phases of cosine curve calculated for Carrhotus xanthogramma (above) and Philodromus cespitum (below). The activity levels at the maximum (Max - i.e. the activity levels at acrophase) and at the minimum (Min - i.e. the activity levels at bathyphase) of the fitted cosine curve and the mean levels of activity (Mean - i.e. the mesor of the fitted curves). Different letters indicate significant differences $(P<0.05)$ within males and females of a species while the asterisks indicate significant differences $\left({ }^{*}=P<0.05,{ }^{* *}=P<\right.$ 0.01 ) between the sexes.

day) and $2.4 \mathrm{~h}$ (10 cycles/day). Interestingly, all the cycles recorded for males were also recorded for females, but not vice versa. In addition, the means of the relative power of ultradian components recorded for females of $\mathrm{Ph}$. cespitum was relatively higher than that recorded for conspecific males or C. xanthogramma. Nine of eleven Ph. cespitum females had particularly strong secondary components of activity, of two cycles per day (12 h), while in two of the 11 females, the 24-h period component was not detectable (at $\alpha<0.01$ significance level) (Fig. 4). For the spectra and relative powers of the significant spectral peaks of the individual spiders in the case of both species, see Supplement S3.

As the 24-h period had a major role in determining the pattern in motor activity, a simple cosine curve or double cosine curve (in Ph. cespitum females, due to the presence of a strong 12-h period component) with a 24-h fixed main period was fitted to the diel pattern of locomotor activity rhythm of both sexes for both species (Fig. 5). The simple cosine curve provided a good fit to the activity rhythms of C. xanthogramma females $\left(\mathrm{R}^{2}=0.857, P<0.001\right)$, males $\left(\mathrm{R}^{2}=0.807, P<0.001\right)$ and $P$. cespitum males $\left(\mathrm{R}^{2}=0.622\right.$, $P<0.001)$. The double cosine curve also provided a good fit to activity data of $P h$. cespitum females $\left(\mathrm{R}^{2}=0.226, P\right.$ $=0.019)$. Comparison of the different parameters obtained from the fitted curves revealed that the factor "phase of activity" had a significant influence on the activity level of both species (C. xanthogramma: $F_{2,36}=1696.41, P<$ 
0.001; Ph. cespitum: $\left.F_{2,38}=100.777, P<0.001\right)$. C. xanthogramma females were significantly more active at the maximum of the fitted curve and females also showed a significantly higher mean activity than males, while $P h$. cespitum males were more active at the maximum of the curve than conspecific females (Fig. 6).

\section{DISCUSSION}

As we hypothesized, the activity of the species studied was not uniformly distributed throughout the day/night cycle, the rhythm was circadian and contained ultradian periodicities, although not both species proved to be diurnal. Nevertheless, as expected, a marked sexual dimorphism was also recorded in the features of the locomotor activity studied (e.g., in activity level, diel distribution, or spectral composition of the rhythm) of C. xanthogram$m a$ and $P h$. cespitum; females and males of both species showed characteristic differences in the circadian rhythm of their locomotor activity.

\section{Carrhotus xanthogramma}

C. xanthogramma like other salticids has a strictly diurnal activity pattern (Foelix, 2011). Females and males have similar activity schedules (Figs 1,3 ) with their mean peak activities occurring in the morning, at similar times (Fig. 2). Their locomotor activity increases with increase in light intensity at dawn, although it seems that males react less strongly to the increase in light intensity than females (Figs 2, 3). Nevertheless, contrary to what we predicted, the mean activity level was significantly higher in C. xanthogramma females than males (Figs 3,6). Although in most spiders the locomotor activity of males is greater than that of females (Schmitt et al., 1990; Foelix, 2011) and the same is true for many jumping spiders (Prószynski \& Lubin, 1993), our results indicate the opposite pattern also occurs. A recent study (Tork, 2018) also reports higher activity in females of the jumping spider Portia fimbriata (Salticidae), suggesting that, in some species of jumping spiders, females are more active than males. One explanation for this might be that jumping spider females forage more intensively than males because they are larger and need more energy for egg production. In contrast, the most important objective for males is to find a mate (Givens, 1978). On the one hand, C. xanthogramma has a relatively narrow breeding window (April-May) (Markó \& Keresztes, 2014), so that males need to find a mate as soon as possible in order to breed successfully, which would result in higher activity. On the other hand, although males are time minimisers in foraging (Givens, 1978) it does not necessarily mean that they spend most of their time searching for a mate. C. xanthogramma males might be exposed to greater risk of predation than females (Markó \& Keresztes, 2014), and thus they may adopt a more careful and safer mate searching strategy requiring less movement in order to avoid predators and potentially dangerous conspecifics and so maximize their breeding success. Further studies are needed to clarify the mechanisms involved in this dynamic. Given that the sexes may differ in their metabolic rate (Kotiaho, 1998; Schmitz, 2004) and their activity levels may be correlated with metabolic rate (Walker \& Irwin, 2006), it is important to have a better understanding of this aspect of their biology in order to interpret the sex-related differences recorded in activity levels of C. xanthogramma.

The locomotor activity of C. xanthogramma was circadian and the one cycle per day was the strongest pattern recorded for both sexes (Figs 4, 5), while the other ultradian periodicities were less obvious, even though statistically they were significant. It should be noted that the ultradian periodicities were only recorded for some individuals. The presence of ultradian spectral components are reported in other spiders (Suter, 1993; Suter \& Benson, 2014); however, their role is still not entirely clear. We hypothesized that the significant spectral components of the activities will be more numerous in males than in females and the males did indeed exhibit more ultradian periodicities than females, but not because they were more active. For rats, the appearance of various ultradian rhythmic components in the daily pattern of locomotor activity is also sex-specific and genetically fixed and might result from the different hormonal environments in the sexes (Wollnik, 1985). However, in spiders, further studies are needed to determine the exact ecological functions of these rhythms and the mentioned sexual differences.

\section{Philodromus cespitum}

As the activity index values (Fig. 1) and the mean resultant lengths ( $R$, which is close to zero, Fig. 2) indicate that $P h$. cespitum is not a diurnal hunter as previously thought (Pekár, 1999a; Korenko et al., 2010) but has a cathemeral activity pattern, which means this spider can be active both in the day and at night (Tattersall, 1987). Furthermore, $P h$. cespitum females and males follow different activity schedules (Figs 1-3): females were significantly more active at night and twilight than males (Fig. 1) and they differed in mean time of their activity peaks. Females had a mean peak activity at night and that of males in the early morning, almost four hours later (Fig. 2). It is known that the females and males of small linyphiid spiders may have different activity patterns (Krumpalová \& Tuf, 2013), which may be a kind of resource partitioning or it may be safer for the males to search for females when they are less active. Furthermore, $P h$. cespitum females increase their activity immediately after the light intensity decreases, at civil dusk, whereas males increased their activity when light intensity increased at nautical dawn (Fig. 3). However, a moderate increase in activity also occurred at dawn in females and at dusk in males (Fig. 2). Somewhat similar bimodal activity rhythms (with two local peaks near dawn and dusk) are reported in other animal taxa (Aschoff, 1966; Pittendrigh, 1981), but in our case, females and males primarily react to two different stimuli (darkening, lightening), which is uncommon.

Our hypothesis that males of Ph. cespitum would be more active than the females was not confirmed (Figs 3, 5, 6 ), as the mean activity levels of the sexes did not differ, although the mean activity of males was numerically greater and they were more active at the maximum of the fitted 
curve than the females. Furthermore, in contrast to our last hypothesis, the presence of ultradian components in the spectral activity pattern of females of $P h$. cespitum were more frequent than in males (Fig. 4). Although daily locomotor activity of $\mathrm{Ph}$. cespitum was found to be dominantly circadian, two females did not exhibit a daily activity cycle. Suter \& Benson (2014) also report that some individuals of Dolomedes triton (Walckenaer, 1837) (Pisauridae) do not have a one cycle per day oscillation in their activity, whereas others do. Furthermore, unlike C. xanthogram$m a$, the relative power of ultradian rhythmic components in Ph. cespitum was stronger, especially in females (Fig. 4). In females, the two cycle per day oscillation seems to be typical because it was recorded for the majority of the individuals and is of relatively high power (Fig. 4). The results of the Fourier analysis indicated a further important difference between the sexes: males had unimodal while females had bimodal activity patterns (Figs 4, 5). As Ph. cespitum has closely related sibling species [e.g., $P h . a u$ reolus (Clerck, 1757), Ph. buchari Kubcová, 2004 or Ph. longipalpis Simon, 1870] in Europe (Kubcová, 2004), it would be worth studying the activity of these sibling species in order to learn more about the unusual activity pattern of philodromids and, potentially, about mechanisms for their reproductive isolation (Schmitt et al., 1990).

The temporal shift in the diel activity of certain species or populations could be driven by predators that are active in the same time window or by the absence of prey (Kronfeld-Schor \& Dayan, 2003). The observed sexual dimorphism in the activity of $P h$. cespitum might, therefore, be explained by the different nutritional needs of the sexes, leading to activity (and foraging) peaks at different times of the day.

\section{CONCLUSION}

Summarizing the results we found the followings: (1) females of $C$. xanthogramma are more active than males, (2) whereas in Ph. cespitum the sexes have different patterns of activity, (3) based on the data for the two species studied the presence of ultradian components possibly does not depend on the total amount of activity, (4) sexes differ in their set of ultradian rhythmic components, (5) strictly diurnal species (C. xanthogramma) have fewer high-frequency oscillations in their locomotor activity rhythm with weaker relative power than in the cathemeral species $(P h$. cespitum) and (6) for Ph. cespitum, in addition to one cycle per day (24-h) oscillation two cycles per day (12-h) oscillation can also play an important role in the temporal pattern in its locomotor activity.

ACKNOWLEDGEMENTS. The authors would like to thank D. Korányi and C. Nagy for their assistance in collecting the spiders, D. Gyóni for analysing the video recordings, P. Dolejš for providing literature and J. Felföldi for determining the peak emission wavelength of our red light source. The first author would also like to thank his wife, S. Mezőfi, for her support and encouragement during the preparation of the manuscript. This study was supported by the National Research, Development and Innovation Office of Hungary (K112743) and by the Higher Educa- tion Institutional Excellence Program (20430-3/2018/FEKUTSTRAT) awarded by the Ministry of Human Capacities within the framework of plant breeding and plant protection researches of Szent István University.

\section{REFERENCES}

Albín A., Aisenberg A., Simó M. \& Dolejš P. 2018: Sexual dimorphism in the spinning apparatus of Allocosa senex (Araneae: Lycosidae), a wolf spider with a reversal in typical sex roles. - J. Arachnol. 46: 207-213.

Aschoff J. 1966: Circadian activity pattern with two peaks. Ecology 47: 657-662.

BogYA S. \& MARKó V. 1999: Effect of pest management systems on ground-dwelling spider assemblages in an apple orchard in Hungary. - Agric. Ecosyst. Environ. 73: 7-18.

Bogya S., Markó V. \& Szinetár C. 1999a: Comparison of pome fruit orchard inhabiting spider assemblages at different geographical scales. - Agric. For. Entomol. 1: 261-269.

Bogya S., Szinetár C. \& Markó V. 1999b: Species composition of spider (Araneae) assemblages in apple and pear orchards in the Carpathian Basin. - Acta Phytopathol. Entomol. Hung. 34: 99-121.

Bogya S., Markó V. \& Szinetár C. 2000: Effect of pest management systems on foliage- and grass-dwelling spider communities in an apple orchard in Hungary. - Int. J. Pest Manag. 46: 241-250.

Cloudsley-Thompson J.L. 1981: A comparison of rhythmic locomotory activity in tropical forest Arthropoda with that in desert species. - J. Arid Environ. 4: 327-334.

Cloudsley-Thompson J.L. 1987: The biorhythms of spiders. In Nentwig W. (ed.): Ecophysiology of Spiders. Springer, Berlin, Heidelberg, pp. 371-379.

Cloudsley-Thompson J.L. 2000: Biological rhythms in Arachnida (excluding Acari). - Mem. Soc. Entomol. Ital. 78: 251-273.

Cornelissen G. 2014: Cosinor-based rhythmometry. - Theor. Biol. Med. Model. 11: 16, 24 pp.

Ensing E.P., Ciuti S., De Wijs F.A.L.M., LentferinK D.H., ten Hoedt A., Boyce M.S. \& Hut R.A. 2014: GPS based daily activity patterns in European red deer and North American elk (Cervus elaphus): indication for a weak circadian clock in ungulates. — PLoS ONE 9(9): e106997, 11 pp.

FAng W.Y., Wang Z.L., Li C., YANG X.Q. \& YU X.P. 2016: The complete mitogenome of a jumping spider Carrhotus xanthogramma (Araneae: Salticidae) and comparative analysis in four salticid mitogenomes. - Genetica 144: 699-709.

Foelix R.F. 2011: Biology of Spiders. 3rd ed. Oxford University Press, Oxford, 419 pp.

Fontúrbel F.E., Candia A.B. \& Botto-Mahan C. 2014: Nocturnal activity patterns of the monito del monte (Dromiciops gliroides) in native and exotic habitats. - J. Mammal. 95: 1199-1206.

ForRest T.G. \& SutER R.B. 1994: The discrete Fourier transform (DFT) in behavioural analysis. - J. Theoret. Biol. 166: 419429.

FRAMENAU V.W. 2005: Gender specific differences in activity and home range reflect morphological dimorphism in wolf spiders (Araneae, Lycosidae). - J. Arachnol. 33: 334-346.

FUJI Y. 1997: Ecological studies on wolf spiders (Araneae: Lycosidae) in a Northwest Area of Kanto Plain, Central Japan. - Acta Arachnol. 46: 5-18.

GHAVAmi S. 2008: The potential of predatory spiders as biological control agents of cotton pests in Tehran provinces of Iran. Asian J. Exp. Sci. 22: 303-306. 
GIVENS R.P. 1978: Dimorphic foraging strategies of a salticid spider (Phidippus audax). - Ecology 59: 309-321.

Head G. 1995: Selection on fecundity and variation in the degree of sexual size dimorphism among spider species (class Araneae). - Evolution 49: 776-781.

Herberstein M.E. \& Elgar M.A. 1994: Foraging strategies of Eriophora transmarina and Nephila plumipes (Araneae: Araneoidea): Nocturnal and diurnal orb-weaving spiders. - Aust. J. Ecol. 19: 451-457.

Hut R.A., Paolucci S., Dor R., Kyriacou C.P. \& Daan S. 2013 Latitudinal clines: an evolutionary view on biological rhythms. _Proc. R. Soc. (B) 280: 20130433, 9 pp.

JACKSON R.R. \& PolLARD S.D. 1996: Predatory behavior of jumping spiders. - Annu. Rev. Entomol. 41: 287-308.

Jones T.C., Akoury T.S., Hauser C.K. \& Moore D. 2011: Evidence of circadian rhythm in antipredator behaviour in the orb-weaving spider Larinioides cornutus. - Anim. Behav. 82: $549-555$.

Jones T.C., Wilson R.J. \& Moore D. 2018: Circadian rhythms of locomotor activity in Metazygia wittfeldae (Araneae: Araneidae). - J. Arachnol. 46: 26-30.

Котіано J.S. 1998: Sexual differences in metabolic rates of spiders. - J. Arachnol. 26: 401-404.

Korenko S., PekÁr S. \& HonĚK A. 2010: Predation activity of two winter-active spiders (Araneae: Anyphaenidae, Philodromidae). - J. Therm. Biol. 35: 112-116.

Kovoor J., Muñoz-Cuevas A. \& Ortega-Escobar J. 1995: Diel morphological changes in the photoreceptors of Lycosa tarentula (Araneae, Lycosidae). - Biol. Rhythm Res. 26: 272-291.

Kovoor J., Ortega-Escobar J. \& MuÑoz-Cuevas A. 1999: Circadian structural changes in the retina of Lycosa tarentula (Araneae: Lycosidae). - Biol. Rhythm Res. 30: 407-423.

Kronfeld-Schor N. \& Dayan T. 2003: Partitioning of time as an ecological resource. - Annu. Rev. Ecol. Evol. Syst. 34: 153181.

Krumpalová Z. \& TuF I.H. 2013: Circadian rhythms of ground living spiders: mechanisms of coexistence strategy based on the body size. - Pol. J. Ecol. 61: 575-586.

Kubcová L. 2004: A new spider species from the group Philodromus aureolus (Araneae, Philodromidae) in Central Europe. —Denisia 12: 291-304.

Lefebvre M., Franck P., Olivares J., Ricard J.-M., Mandrin J.-F. \& LAVIGNE C. 2017: Spider predation on rosy apple aphid in conventional, organic and insecticide-free orchards and its impact on aphid populations. - Biol. Contr. 104: 57-65.

MaEKaWA T. \& IkedA H. 1992: Sexual behaviour of a gynandromorphic spider of Carrhotus xanthogramma (Araneae: Salticidae). - Acta Arachnol. 41: 103-108 [in Japanese with an English abstr.].

Marc P., Canard A. \& Ysnel F. 1999: Spiders (Araneae) useful for pest limitation and bioindication. - Agric. Ecosyst. Environ. 74: 229-273.

MARKó V. \& KeRESZTes B. 2014: Flowers for better pest control? Ground cover plants enhance apple orchard spiders (Araneae), but not necessarily their impact on pests. - Biocontr. Sci. Technol. 24: 574-596.

Menegazzi P., Vanin S., Yoshit T., Rieger D., Hermann C., Dusik V., Kyriacou C.P., Helfrich-Förster C. \& Costa R. 2013 Drosophila clock neurons under natural conditions. - J. Biol. Rhythm. 28: 3-14.

Mezöfi L., Nagy C., KorÁnyi D. \& Markó V. 2018: Preliminary data on the natural prey of arboreal hunting spiders (Araneae) in apple orchards. In Mezöfi L. \& Szita É. (eds): Final Program and Abstracts of $31^{\text {st }}$ European Congress of Arachnology, Vác, Hungary, July 8-13, 2018. Budapest, p. 96.
Michalko R. \& KošUlič O. 2016: Temperature-dependent effect of two neurotoxic insecticides on predatory potential of Philodromus spiders. - J. Pest Sci. 89: 517-527.

Michalko R. \& PekÁr S. 2015: The biocontrol potential of Philodromus (Araneae, Philodromidae) spiders for the suppression of pome fruit orchard pests. - Biol. Contr. 82: 13-20.

Michalko R., Petráková L., Sentenská L. \& Pekár S. 2017: The effect of increased habitat complexity and density-dependent non-consumptive interference on pest suppression by winteractive spiders. - Agric. Ecosyst. Environ. 242: 26-33.

Miliczky E.R., Horton D.R. \& CALKIns C.O. 2008: Observations on phenology and overwintering of spiders associated with apple and pear orchards in south-central Washington. - $J$. Arachnol. 36: 565-573.

Moore D., Watts J.C., Herrig A. \& Jones T.C. 2016: Exceptionally short-period circadian clock in Cyclosa turbinata: regulation of locomotor and web-building behavior in an orb-weaving spider. - J. Arachnol. 44: 388-396.

Nentwig W., Blick T., Gloor D., Hänggi A. \& Kropf C. 2018: Araneae: Spiders of Europe. Vers. 11.2018. URL: http://www. araneae.nmbe.ch.

Nørgaard T., Henschel J.R. \& Wehner R. 2006: The night-time temporal window of locomotor activity in the Namib Desert long-distance wandering spider, Leucorchestris arenicola. J. Comp. Physiol. (A) 192: 365-372.

ORTEGA-EsCoBAR J. 2002a: Circadian rhythms of locomotor activity in Lycosa tarentula (Araneae, Lycosidae) and the pathways of ocular entrainment. - Biol. Rhythm Res. 33: 561-576.

ORTEGA-Escobar J. 2002b: Evidence that the wolf-spider Lycosa tarentula (Araneae, Lycosidae) needs visual input for path integration. - J. Arachnol. 30: 481-486.

Ortega J., Ruiz M. \& Fernandez-Montraveta C. 1992: Daily patterns of locomotor activity in a lycosid spider. - J. Interdiscipl. Cycle Res. 23: 295-301.

PéÁr S. 1999a: Foraging mode: a factor affecting the susceptibility of spiders (Araneae) to insecticide applications. - Pesticide Sci. 55: 1077-1082.

PeKÁr S. 1999b: Effect of IPM practices and conventional spraying on spider population dynamics in an apple orchard. Agric. Ecosyst. Environ. 73: 155-166.

PeKÁR S. \& JARAB M. 2011: Life-history constraints in inaccurate Batesian myrmecomorphic spiders (Araneae: Corinnidae, Gnaphosidae). - Eur. J. Entomol. 108: 255-260.

Péár S. \& Kocourek F. 2004: Spiders (Araneae) in the biological and integrated pest management of apple in the Czech Republic. - J. Appl. Entomol. 128: 561-566.

Pekár S., Michalko R., Loverre P., Líznarová E. \& Černecká L. 2015: Biological control in winter: novel evidence for the importance of generalist predators. - J. Appl. Ecol. 52: 270-279.

PÉTER A. 2011: Solomon Coder Version Beta 17.03.22: A Simple Solution for Behavior Coding. URL: http://solomoncoder.com (last accessed 4 March 2018).

PitTendRigh C.S. 1981: Circadian systems: entrainment. In Aschoff J. (ed.): Biological Rhythms. Plenum Press, New York, pp. 95-124.

Prószynski J. \& Lubin Y. 1993: Pitfall trapping of Salticidae (Araneae) in the Negev Desert. - Boll. Acc. Gioenia Sci. Nat. 26: 281-291.

R Core TeAm 2018: R: A Language and Environment for Statistical Computing. R Foundation for Statistical Computing, Vienna. URL: https://www.R-project.org/.

RÁdAi Z., NÉMETH Z. \& BARTA Z. 2018: Sex-dependent immune response in a semelparous spider. - Sci. Nat. 105: 39, 4 pp. 
Ranganathan Y., Ghara M. \& Borges R.M. 2010: Temporal associations in fig-wasp-ant interactions: diel and phenological patterns. - Entomol. Exp. Appl. 137: 50-61.

Refinetti R. 2016: Circadian Physiology. 3rd ed. CRC Press, Boca Raton, FL, 714 pp.

ŘEzÁČ M., PekÁr S. \& Stará J. 2010: The negative effect of some selective insecticides on the functional response of a potential biological control agent, the spider Philodromus cespitum. BioControl 55: 503-510.

SAckett T.E., Buddle C.M. \& Vincent C. 2008: Comparisons of the composition of foliage-dwelling spider assemblages in apple orchards and adjacent deciduous forest. - Can. Entomol. 140: 338-347.

Schmitt A., Schuster M. \& Barth F.G. 1990: Daily locomotor activity patterns in three species of Cupiennius (Araneae, Ctenidae): The males are the wandering spiders. - J. Arachnol. 18: $249-255$

Schmitz A. 2004: Metabolic rates during rest and activity in differently tracheated spiders (Arachnida, Araneae): Pardosa lugubris (Lycosidae) and Marpissa muscosa (Salticidae). - J. Comp. Physiol. (B) 174: 519-526.

SLATKIN M. 1984: Ecological causes of sexual dimorphism. Evolution 38: 622-630.

Soriano-Morales S., Caballero-Hernández O., Dávila-Montes M., Morales-Malacara J.B. \& Miranda-Anaya M. 2013: Circadian locomotor activity and entrainment by light cycles in cave spiders (Dipluridae and Ctenidae) at the cave Los Riscos, Qro. México. - Biol. Rhythm Res. 44: 949-955.

Sullivan H.L. \& Morse D.H. 2004: The movement and activity patterns of similar-sized adult and juvenile crab spiders Misumena vatia (Araneae, Thomisidae). - J. Arachnol. 32: 276-283.

Suter R.B. 1993: Circadian rhythmicity and other patterns of spontaneous motor activity in Frontinella pyramitela (Linyphiidae) and Argyrodes trigonum (Theridiidae). — J. Arachnol. 21: $6-22$.

Suter R.B. \& Benson K. 2014: Nocturnal, diurnal, crepuscular: activity assessments of Pisauridae and Lycosidae. - J. Arachnol. 42: 178-191.

TATTERSALL I. 1987: Cathemeral activity in primates: a definition. - Folia Primatol. 49: 200-202.

The MathWorks Inc. 2015: MATLAB: The Language of Technical Computing. Ver. 8.5.0 (R2015a). Natick, MA.
Tietjen W.J. \& Cady A.B. 2007: Sublethal exposure to a neurotoxic pesticide affects activity rhythms and patterns of four spider species. - J. Arachnol. 35: 396-406.

TopPING C.J. \& SunderLand K.D. 1992: Limitations to the use of pitfall traps in ecological studies exemplified by a study of spiders in a field of winter wheat. - J. Appl. Ecol. 29: 485-491.

TORK P. 2018: Temporal Behavior in Jumping Spiders (Araneae, Salticidae). PhD Thesis, University of Canterbury, Christchurch, $142 \mathrm{pp}$.

Turk E., Kuntner M. \& Kralu-FIšEr S. 2018: Cross-sex genetic correlation does not extend to sexual size dimorphism in spiders. - Sci. Nat. 105: 1, 8 pp.

Uetz G.W., Halaj J. \& Cady A.B. 1999: Guild structure of spiders in major crops. - J. Arachnol. 27: 270-280.

USNO 2018: Rise, Set, and Twilight Definitions. United States Naval Observatory (USNO) Astronomical Applications Department. URL: http://aa.usno.navy.mil/faq/docs/RST_defs. php (last accessed 24 Jan. 2018).

Vanin S., Bhutani S., Montelli S., Menegazzi P., Green E.W., Pegoraro M., Sandrelli F., Costa R. \& Kyriacou C.P. 2012: Unexpected features of Drosophila circadian behavioural rhythms under natural conditions. - Nature 484: 371-375.

WALKER S.E. \& IRWIN J.T. 2006: Sexual dimorphism in the metabolic rate of two species of wolf spider (Araneae, Lycosidae). - J. Arachnol. 34: 368-373.

Wisniewska J. \& Prokopy R.J. 1997: Do spiders (Araneae) feed on rose leafhopper (Edwardsiana rosae; Auchenorrhyncha: Cicadellidae) pests of apple trees? - Eur. J. Entomol. 94: 243-251.

WOLLNIK F. 1985: Sex differences in the daily pattern of locomotor activity in laboratory rats. - Naturwissenschaften $\mathbf{7 2}$ : 158-161.

WSC 2018: World Spider Catalog. Ver. 19.0. Natural History Museum, Bern. URL: http://wsc.nmbe.ch.

YAMASHITA S. 2002: Efferent innervation of photoreceptors in spiders. - Microsc. Res. Tech. 58: 356-364.

YAMASHITA S. \& NAKAMURA T. 1999: Circadian oscillation of sensitivity of spider eyes: diurnal and nocturnal spiders. - J. Exp. Biol. 202: 2539-2542.

YoshidA H. \& SUZUKI Y. 1981: Silk as a cue for mate location in the jumping spider, Carrhotus xanthogramma (Latreille) (Araneae: Salticidae). - Appl. Entomol. Zool. 16: 315-317.

Received January 31, 2019; revised and accepted April 23, 2019 Published online May 28, 2019 


\section{Supplement S1. Spiders used in the experiment and information about the collecting sites.}

Table S1-1. Spiders used in the experiment and information about the collecting sites.

\begin{tabular}{|c|c|c|c|c|c|c|}
\hline ID & Mass (mg) & Sex & Date collected & Collecting sites $^{a}$ & Coordinates & Treatment \\
\hline \multicolumn{7}{|c|}{ Carrhotus xanthogramma } \\
\hline C_x_a_1 & 13.10 & female & 2016.04.16 & Újfehértó & $47^{\circ} 49^{\prime} 13^{\prime \prime} \mathrm{N}, 21^{\circ} 39^{\prime} 58^{\prime \prime} \mathrm{E}$ & organic \\
\hline C_x_a_2 & 26.30 & male & 2016.04 .16 & Újfehértó & $47^{\circ} 49^{\prime} 13^{\prime \prime} \mathrm{N}, 21^{\circ} 39^{\prime} 58^{\prime \prime} \mathrm{E}$ & organic \\
\hline C_x_a_3 & 24.20 & female & 2016.04 .16 & Újfehértó & $47^{\circ} 49^{\prime} 13^{\prime \prime} \mathrm{N}, 21^{\circ} 39^{\prime} 58^{\prime \prime} \mathrm{E}$ & organic \\
\hline C_x_a_4 & 22.00 & male & 2016.04 .16 & Újfehértó & $47^{\circ} 49^{\prime} 13^{\prime \prime} \mathrm{N}, 21^{\circ} 39^{\prime} 58^{\prime \prime} \mathrm{E}$ & organic \\
\hline C_x_a_5 & 21.10 & female & 2016.04 .16 & Újfehértó & $47^{\circ} 49^{\prime} 13^{\prime \prime} \mathrm{N}, 21^{\circ} 39^{\prime} 58^{\prime \prime} \mathrm{E}$ & organic \\
\hline C_x_a_6 & 23.10 & male & 2016.04 .16 & Újfehértó & $47^{\circ} 49^{\prime} 13^{\prime \prime} \mathrm{N}, 21^{\circ} 39^{\prime} 58^{\prime \prime} \mathrm{E}$ & organic \\
\hline C_x_a_7 & 29.20 & male & 2016.04 .16 & Újfehértó & $47^{\circ} 49^{\prime} 13^{\prime \prime} \mathrm{N}, 21^{\circ} 39^{\prime} 58^{\prime \prime} \mathrm{E}$ & organic \\
\hline C_x_a_8 & 27.90 & female & 2016.04 .16 & Újfehértó & $47^{\circ} 49^{\prime} 13^{\prime \prime} \mathrm{N}, 21^{\circ} 39^{\prime} 58^{\prime \prime} \mathrm{E}$ & organic \\
\hline $\mathrm{C}^{-} \times \mathrm{a}^{-} 9$ & 27.10 & male & 2016.04 .16 & Újfehértó & $47^{\circ} 49^{\prime} 13^{\prime \prime} \mathrm{N}, 21^{\circ} 39^{\prime} 58^{\prime \prime} \mathrm{E}$ & organic \\
\hline C_x_a_10 & 25.10 & female & 2016.04 .16 & Újfehértó & $47^{\circ} 49^{\prime} 13^{\prime \prime} \mathrm{N}, 21^{\circ} 39^{\prime} 58^{\prime \prime} \mathrm{E}$ & organic \\
\hline C_x_a_11 & 30.80 & male & 2016.04 .16 & Újfehértó & $47^{\circ} 49^{\prime} 13^{\prime \prime N}, 21^{\circ} 39^{\prime} 58^{\prime \prime} \mathrm{E}$ & organic \\
\hline C_x_a_12 & 21.30 & female & 2016.04 .16 & Újfehértó & $47^{\circ} 49^{\prime} 13^{\prime \prime} \mathrm{N}, 21^{\circ} 39^{\prime} 58^{\prime \prime} \mathrm{E}$ & organic \\
\hline$c \times a 13$ & 28.20 & female & 2016.04 .16 & Újfehértó & $47^{\circ} 49^{\prime} 13^{\prime \prime} \mathrm{N}, 21^{\circ} 39^{\prime} 58^{\prime \prime} \mathrm{E}$ & organic \\
\hline C_x_a_14 & 30.70 & male & 2016.04 .16 & Újfehértó & $47^{\circ} 49^{\prime} 13^{\prime \prime} \mathrm{N}, 21^{\circ} 39^{\prime} 58^{\prime \prime} \mathrm{E}$ & organic \\
\hline C_x_a_15 & 21.60 & female & 2016.04 .16 & Újfehértó & $47^{\circ} 49^{\prime} 13^{\prime \prime} \mathrm{N}, 21^{\circ} 39^{\prime} 58^{\prime \prime} \mathrm{E}$ & organic \\
\hline C_x_a_16 & 18.80 & male & 2016.04 .16 & Újfehértó & $47^{\circ} 49^{\prime} 13^{\prime \prime} \mathrm{N}, 21^{\circ} 39^{\prime} 58^{\prime \prime} \mathrm{E}$ & organic \\
\hline C_x_a_17 & 26.80 & female & 2016.04 .16 & Újfehértó & $47^{\circ} 49^{\prime} 13^{\prime \prime} \mathrm{N}, 21^{\circ} 39^{\prime} 58^{\prime \prime} \mathrm{E}$ & organic \\
\hline C_x_a_18 & 22.60 & male & 2016.04 .16 & Újfehértó & $47^{\circ} 49^{\prime} 13^{\prime \prime} \mathrm{N}, 21^{\circ} 39^{\prime} 58^{\prime \prime} \mathrm{E}$ & organic \\
\hline C_x_a_19 & 22.40 & male & 2016.04 .16 & Újfehértó & $47^{\circ} 49^{\prime} 13^{\prime \prime} \mathrm{N}, 21^{\circ} 39^{\prime} 58^{\prime \prime} \mathrm{E}$ & organic \\
\hline$c \times a 20$ & 23.60 & female & 2016.04 .16 & Újfehértó & $47^{\circ} 49^{\prime} 13^{\prime \prime} \mathrm{N}, 21^{\circ} 39^{\prime} 58^{\prime \prime} \mathrm{E}$ & organic \\
\hline C_x_a_21 ${ }^{*}$ & 13.90 & female & 2016.04 .16 & Újfehértó & $47^{\circ} 49^{\prime} 13^{\prime \prime} \mathrm{N}, 21^{\circ} 39^{\prime} 58^{\prime \prime} \mathrm{E}$ & organic \\
\hline \multicolumn{7}{|c|}{ Philodromus cespitum } \\
\hline NAGY_03 & 5.70 & male & 2016.05.09 & Nagykálló & $47^{\circ} 53^{\prime} 17^{\prime \prime} \mathrm{N}, 21^{\circ} 48^{\prime} 56^{\prime \prime} \mathrm{E}$ & organic \\
\hline SZIG 13 & 8.50 & female & 2016.05 .26 & Sziqetszentmiklós & $47^{\circ} 21^{\prime} 53^{\prime \prime} \mathrm{N}, 19^{\circ} 00^{\prime} 19^{\prime \prime} \mathrm{E}$ & abandoned \\
\hline SZIG 12 & 7.20 & male & 2016.05 .26 & Szigetszentmiklós & $47^{\circ} 21^{\prime} 53^{\prime \prime N}, 19^{\circ} 00^{\prime} 19^{\prime \prime} \mathrm{E}$ & abandoned \\
\hline SZIG_11 & 6.80 & female & 2016.05 .26 & Szigetszentmiklós & $47^{\circ} 21^{\prime} 53^{\prime \prime} \mathrm{N}, 19^{\circ} 00^{\prime} 19^{\prime \prime} \mathrm{E}$ & abandoned \\
\hline KOCS_02 & 7.50 & male & 2016.05 .10 & Kocsord & $47^{\circ} 56^{\prime} 26^{\prime \prime} \mathrm{N}, 22^{\circ} 24^{\prime} 13^{\prime \prime} \mathrm{E}$ & IPM \\
\hline SZIG_15 & 9.30 & female & 2016.05 .26 & Szigetszentmiklós & $47^{\circ} 21^{\prime} 53^{\prime \prime} \mathrm{N}, 19^{\circ} 00^{\prime} 19^{\prime \prime} \mathrm{E}$ & abandoned \\
\hline UJF_12 & 6.40 & male & 2016.05 .10 & Újfehértó & $47^{\circ} 49^{\prime} 13^{\prime \prime} \mathrm{N}, 21^{\circ} 39^{\prime} 58^{\prime \prime} \mathrm{E}$ & organic \\
\hline OKOR_09 & 11.50 & female & 2016.05 .10 & Ököritófülpös & $47^{\circ} 55^{\prime} 21^{\prime \prime} \mathrm{N}, 22^{\circ} 27^{\prime} 51^{\prime \prime} \mathrm{E}$ & organic \\
\hline OKOR_16* & 6.10 & male & 2016.05 .10 & Ököritófülpös & $47^{\circ} 55^{\prime} 21^{\prime \prime} \mathrm{N}, 22^{\circ} 27^{\prime} 51^{\prime \prime} \mathrm{E}$ & organic \\
\hline UJF $1 \overline{1}$ & 9.50 & female & 2016.05 .10 & Újfehértó & $47^{\circ} 49^{\prime} 13^{\prime \prime} \mathrm{N}, 21^{\circ} 39^{\prime} 58^{\prime \prime} \mathrm{E}$ & organic \\
\hline KOCS_16 & 10.20 & male & 2016.05 .10 & Kocsord & $47^{\circ} 56^{\prime} 26^{\prime \prime} \mathrm{N}, 22^{\circ} 24^{\prime} 13^{\prime \prime} \mathrm{E}$ & IPM \\
\hline UJF_04 & 12.60 & female & 2016.05 .10 & Újfehértó & $47^{\circ} 49^{\prime} 13^{\prime \prime} \mathrm{N}, 21^{\circ} 39^{\prime} 58^{\prime \prime} \mathrm{E}$ & organic \\
\hline UJF_19* & 4.80 & male & 2016.05 .10 & Újfehértó & $47^{\circ} 49^{\prime} 13^{\prime \prime} \mathrm{N}, 21^{\circ} 39^{\prime} 58^{\prime \prime} \mathrm{E}$ & organic \\
\hline UJF_20 & 8.90 & female & 2016.05 .10 & Újfehértó & $47^{\circ} 49^{\prime} 13^{\prime \prime} \mathrm{N}, 21^{\circ} 39^{\prime} 58^{\prime \prime} \mathrm{E}$ & organic \\
\hline FULP_26 & 8.80 & male & 2016.05 .10 & Fülpösdaróc & $47^{\circ} 56^{\prime} 18^{\prime \prime} \mathrm{N}, 22^{\circ} 29^{\prime} 17^{\prime \prime} \mathrm{E}$ & organic \\
\hline FULP_24 & 10.10 & female & 2016.05 .10 & Fülpösdaróc & $47^{\circ} 56^{\prime} 18^{\prime \prime} \mathrm{N}, 22^{\circ} 29^{\prime} 17^{\prime \prime} \mathrm{E}$ & organic \\
\hline $\mathrm{ROH} \_19$ & 7.30 & male & 2016.05 .09 & Rohod & $48^{\circ} 00^{\prime} 58^{\prime \prime} \mathrm{N}, 22^{\circ} 08^{\prime} 10^{\prime \prime} \mathrm{E}$ & IPM \\
\hline NAGY 20 & 7.40 & male & 2016.05.09 & Nagykálló & $47^{\circ} 53^{\prime} 17^{\prime \prime} \mathrm{N}, 21^{\circ} 48^{\prime} 56^{\prime \prime} \mathrm{E}$ & organic \\
\hline SUK_29 & 10.10 & female & 2016.05 .17 & Sükösd & $46^{\circ} 17^{\prime} 60^{\prime \prime} \mathrm{N}, 19^{\circ} 00^{\prime} 21^{\prime \prime} \mathrm{E}$ & organic \\
\hline UJF_30 & 7.20 & male & 2016.05 .10 & Újfehértó & $47^{\circ} 49^{\prime} 13^{\prime \prime} \mathrm{N}, 21^{\circ} 39^{\prime} 58^{\prime \prime} \mathrm{E}$ & organic \\
\hline UJF 24 & 9.80 & female & 2016.05 .10 & Úifehértó & $47^{\circ} 49^{\prime} 13^{\prime \prime} \mathrm{N}, 21^{\circ} 39^{\prime} 58^{\prime \prime} \mathrm{E}$ & organic \\
\hline MON_16 & 8.40 & female & 2016.05 .18 & Monorierdő & $47^{\circ} 19^{\prime} 11^{\prime \prime} \mathrm{N}, 19^{\circ} 31^{\prime} 13^{\prime \prime} \mathrm{E}$ & organic \\
\hline
\end{tabular}

* specimens excluded from the analysis because of their early death; ${ }^{\text {a }}$ apple orchards. 


\section{Supplement S2. Activity matrix for each species and sex based on individual activity scores}

We used the three-values $(0,1,2)$ of the activity scores to quantify the activity of the spiders both at the individualand species-levels. We provide a coloured activity matrix (based on the untransformed time-series) for each species and sex in which the numerical activity scores are in blue, green and yellow, which indicate whether the spiders were motionless, slightly active or active, respectively. The vertical dimension of the matrix exemplifies the temporal aspect of the spider's activity, while horizontally the coloured time-series for each individual belonging to the same species and sex are plotted, side by side. The colour textures of the matrices clearly represent the spider's activity rhythms, as well as the common behavioural patterns of the species.
A

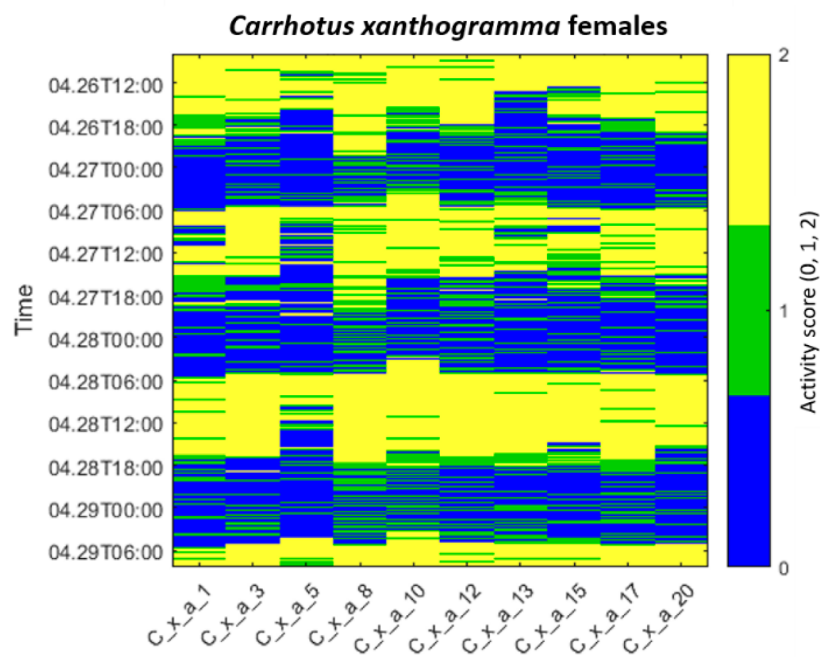

B

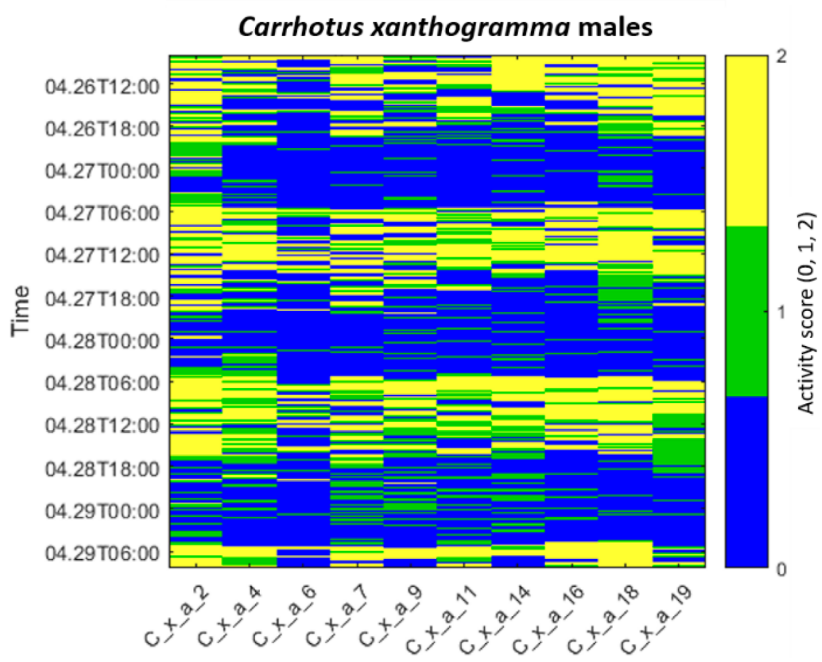

Fig. S2-1. The coloured activity matrices of individual female (A) and male (B) Carrhotus xanthogramma. The blue, green and yellow colours correspond to motionless, slightly active and active states, respectively. The variation in the activity scores is indicated by the colours in terms of time (vertical dimension, at a 10-min resolution) and individuals (horizontal dimension).

A

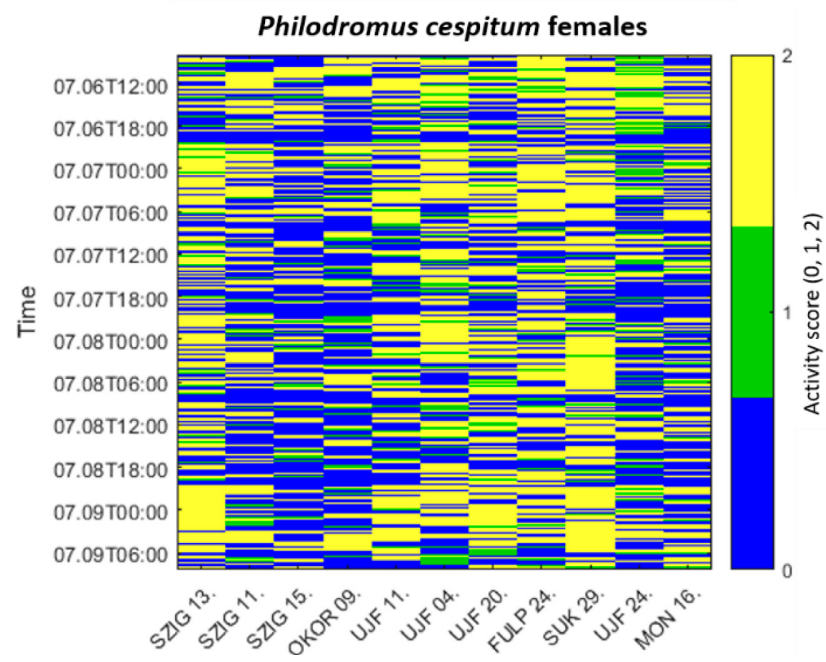

Fig. S2-2. Same as Fig. S2-1 for Philodromus cespitum.
$\mathrm{B}$

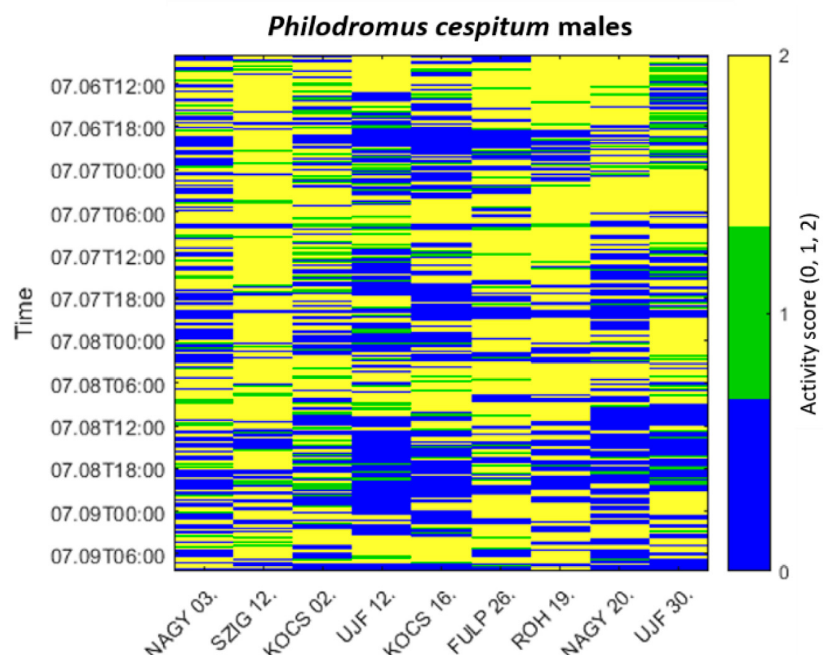




\section{Supplement S3. Spectral parameters and relative powers of the significant spectral peaks of individual spiders}

The recorded power spectra are shown in Figs S3-1A, B and S3-2A, B, where the frequency axes are scaled in terms of multiples of $1 /$ day. The biggest frequency in the spectra is 24 in 1/day units, corresponding to the cut-off frequency of our low-pass filtering $(1 / \mathrm{h})$.

In the spectra (Figs S3-1A, B and S3-2A, B), the power limits are demarcated by the red horizontal lines while the statistically significant peaks in the spider's spectra are represented by red stars. In order to discriminate the sig- nificant periodicities in the spectra at an individual-level, as well as to check the relevance of the different spectral peaks, we present their relative powers (for the definition, see the main text) by different colours in filled discrete contour plots (Figs S3-3A, B and S3-4A, B) where the horizontal and vertical dimensions belong, respectively, to different individuals and the $n$ numbers of daily activity cycles. Since the frequency resolution of the spectra is better than the selected scale of the vertical dimension, the peak frequencies were binned with resolution of 1/day and the sum of the relative powers of bin elements were represented in the contour plots.
A

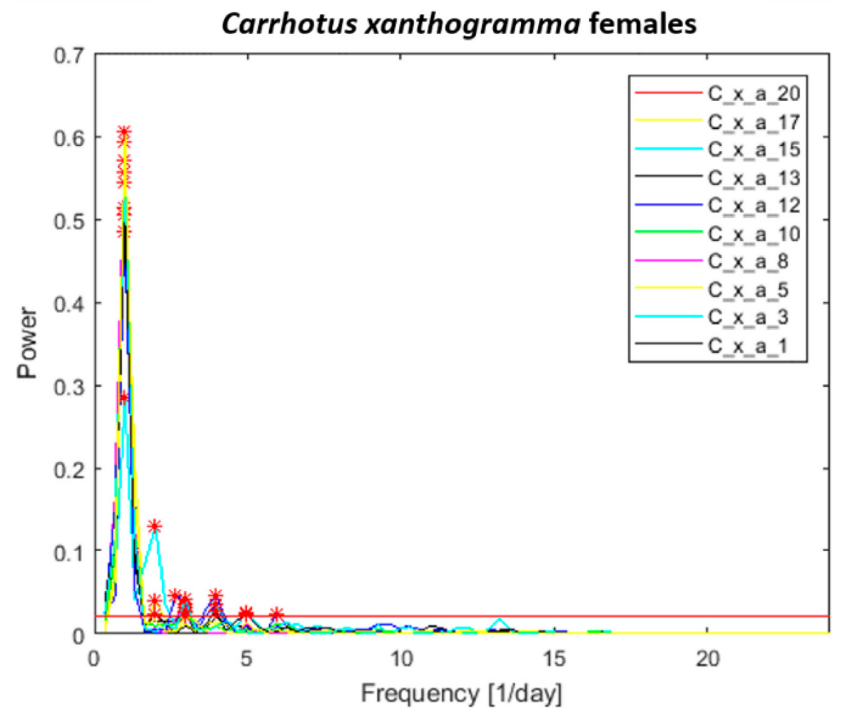

B

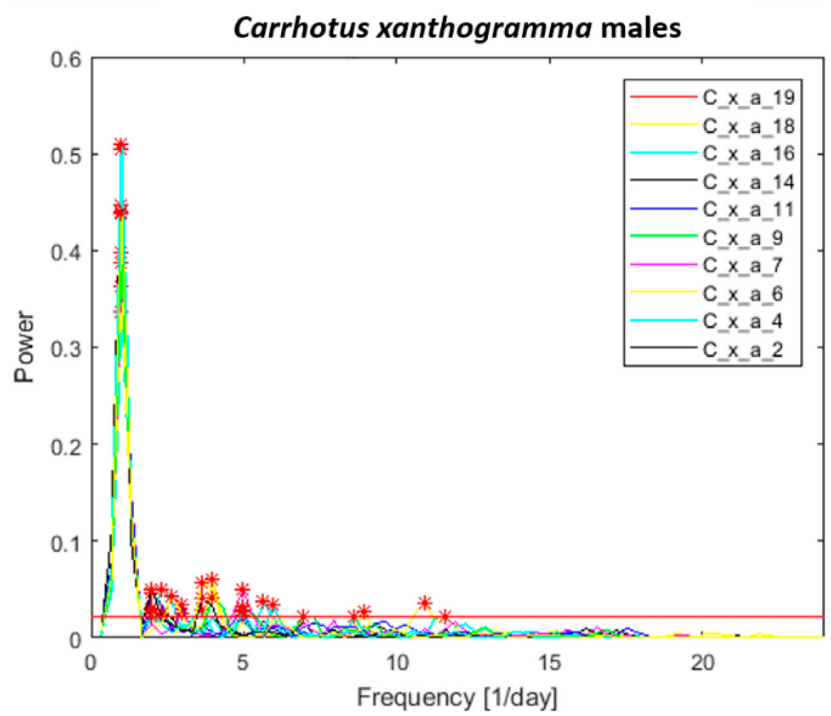

Fig. S3-1. Power spectra of the low-pass filtered (see text) time series of individual female (A) and male (B) Carrhotus xanthogramma. The horizontal red line represents the power limit beyond which the spectral peaks are considered to be significant. The significant periodicities are indicated by red stars.

A

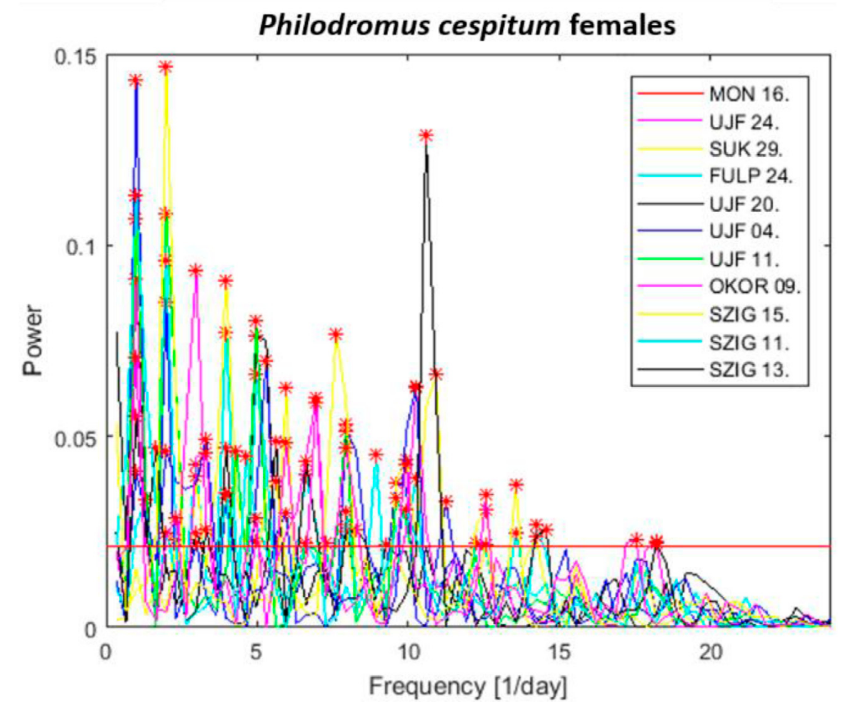

B

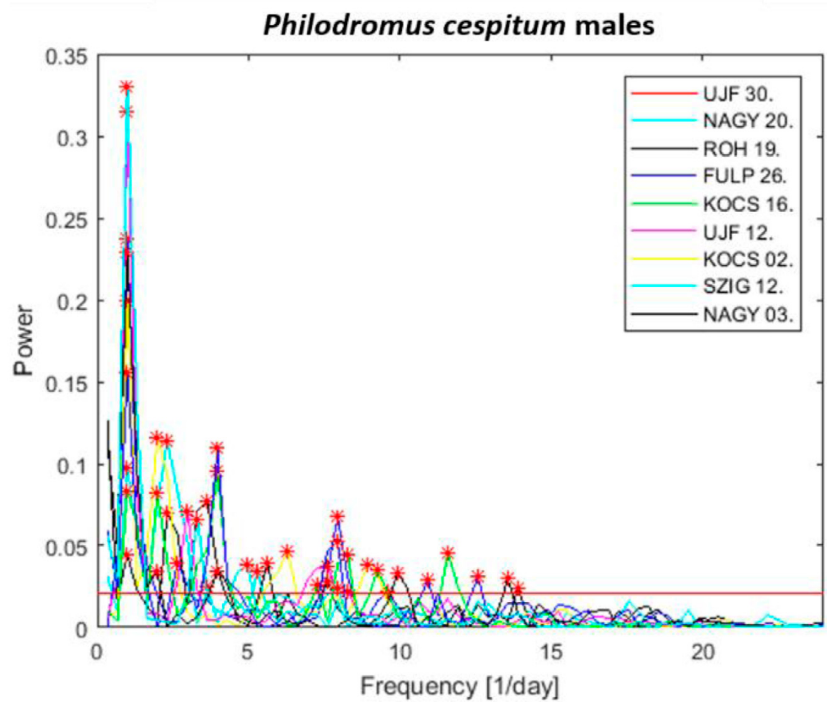

Fig. S3-2. Same as Fig. S3-1 for Philodromus cespitum. 
A

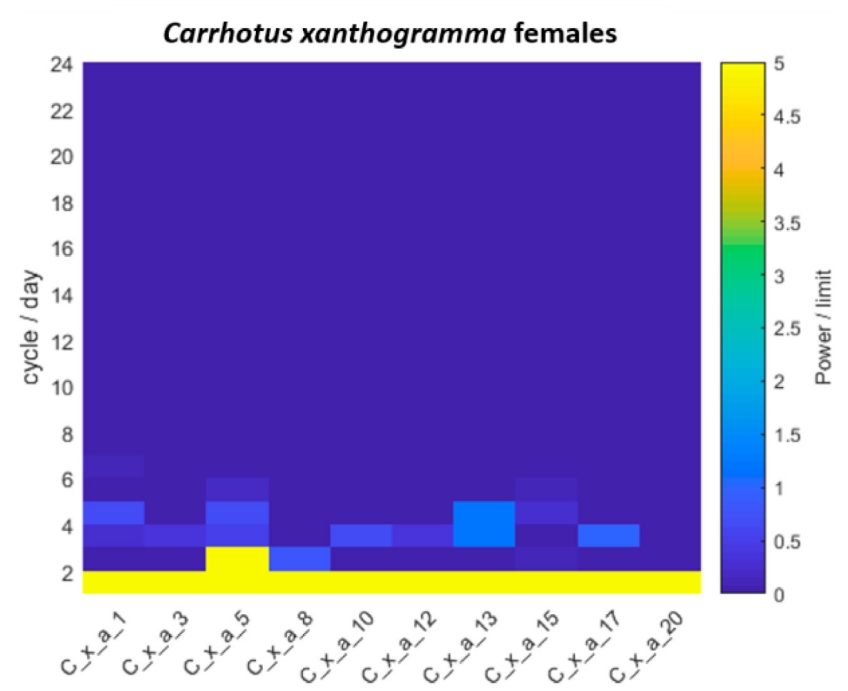

\section{B}

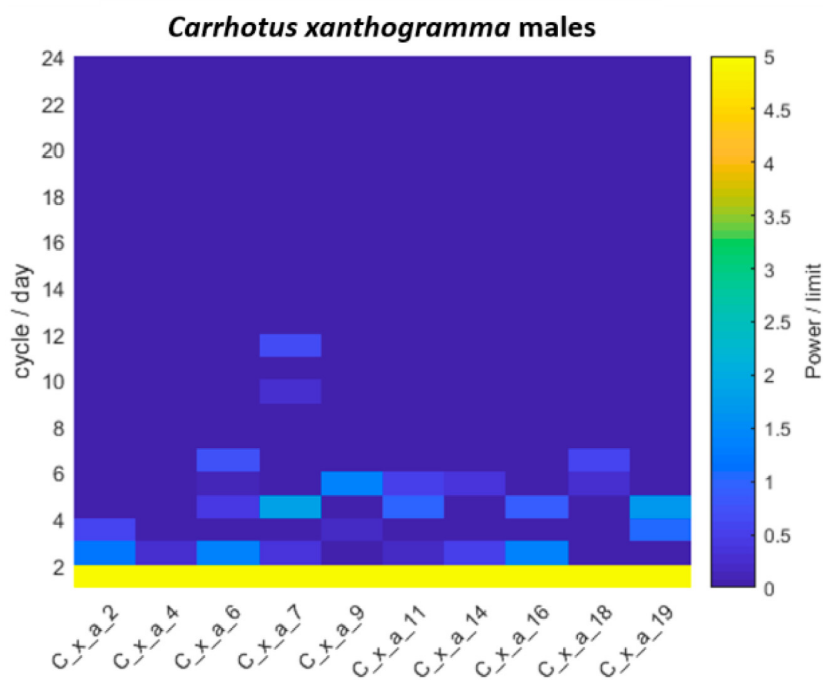

Fig. S3-3. Colour-scale representation of the relative powers of the significant spectral peaks of individual female (A) and male (B) Carrhotus xanthogramma (individuals indicated along the $\mathrm{X}$ axis), in terms of frequency given in cycles/day.

A

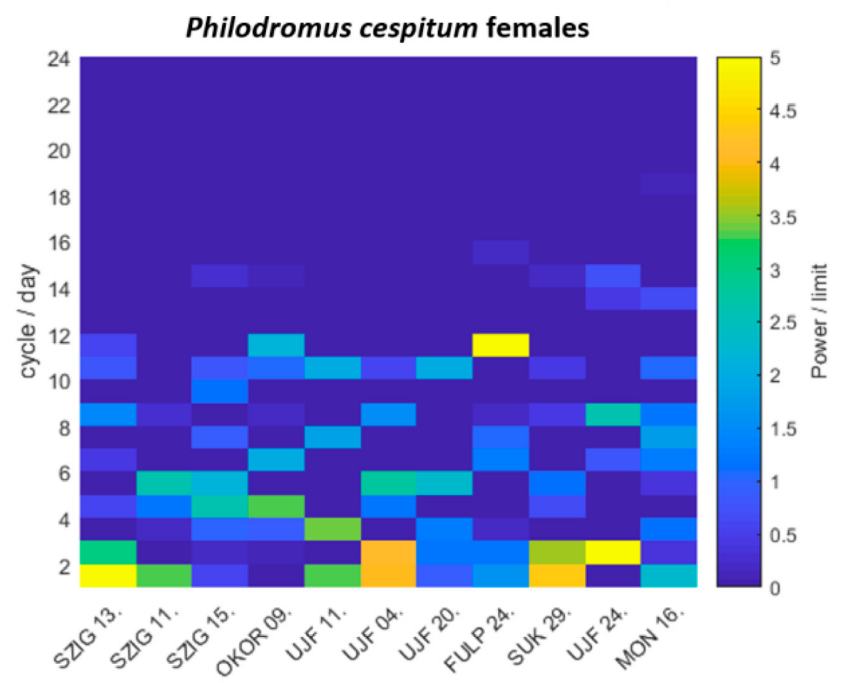

B

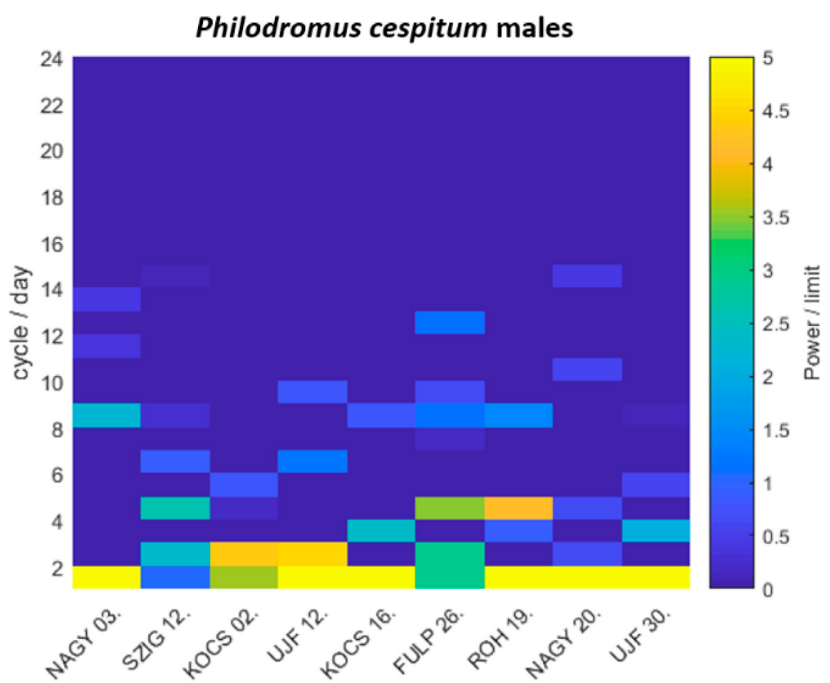

Fig. S3-4. Same as Fig. S3-3 for Philodromus cespitum. 